EPTD DISCUSSION PAPER NO. 65

\title{
THE ROLE OF TREES FOR SUSTAINABLE MANAGEMENT OF LESS-FAVORED LANDS: \\ THE CASE OF EUCALYPTUS IN ETHIOPIA
}

Pamela Jagger and John Pender

\author{
Environment and Production Technology Division \\ International Food Policy Research Institute \\ 2033 K Street, N.W. \\ Washington, D.C. 20006 U.S.A.
}

June 2000

EPTD Discussion Papers contain preliminary material and research results, and are circulated prior to a full peer review in order to stimulate discussion and critical comment. It is expected that most Discussion Papers will eventually be published in some other form, and that their content may also be revised. 


\begin{abstract}
In recent years the planting of eucalyptus trees in Ethiopia has expanded from State owned plantations to community woodlots and household compounds. In an environment suffering from severe woody biomass shortages water scarcity, erosion and land degradation, fast growing and resilient eucalyptus species perform better than most indigenous woodland and forest tree species (as well as most crops). In addition to increasing biomass and providing ground cover, the sale of eucalyptus poles and products has substantial potential to raise farm incomes, reduce poverty, increase food security and diversify smallholder-farming systems in less-favored areas of northern Ethiopia.

Despite the potential for eucalyptus to improve rural livelihoods in northern Ethiopia in 1997, the regional government of Tigray imposed a ban on eucalyptus tree planting on farmlands. This ban is related to concerns regarding potential negative environmental externalities associated with eucalyptus and also due to the desire to reserve productive farmland for crop production. The regional government promotes planting of eucalyptus and other species in community woodlots, and has recently begun to allow private planting of eucalyptus on community wasteland and steep hillsides.

In this paper, we review the debate about the ecological impacts of eucalyptus trees, as well as the economic factors that influence whether smallholders invest in these trees. Ex ante benefit-cost analysis based on community level survey data from Tigray illustrates that under most conditions planting eucalyptus trees yields high rates of return, well above $20 \%$ under most circumstances. The effect of variable harvest rates, the costs of decreased crop production when eucalyptus trees are planted on farmlands, and differences between administrative zones are considered relative to our base case in our rate of return estimates. The importance of fast growing tree species that can accommodate the high discount rates associated with smallholders in this region is emphasized.
\end{abstract}

Based upon the review of ecological and economic impacts of eucalyptus, several policy options are considered. The policy option with the largest potential economic benefits appears to be increasing allocation of wastelands for private tree planting. This option could increase average household income and wealth substantially, and offers large potential direct benefits to landless and land poor households who could be priority recipients of such land. The ecological risks are limited and the potential ecological benefits are large since this option would be implemented in degraded areas. This and other options could help make eucalyptus growing an important pathway of development in northern Ethiopia. 


\section{CONTENTS}

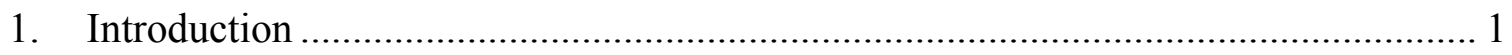

2. Ethiopia's History of Reforestation and Afforestation............................................... 4

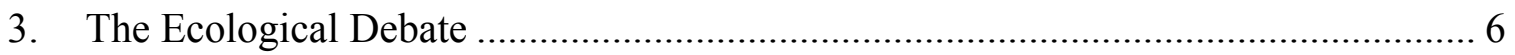

Provision of Biomass and Maintenance of Existing Forest Cover........................ 7

Effects on Soils: Nutrient Depletion, Moisture and Topsoil Retention ............... 11

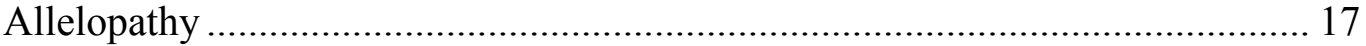

Hydrological Impacts .................................................................................. 19

Resistance to Destructive Pests, Climate Variability and Other Random

Disturbances ............................................................................................... 21

Discussion—The Ecological Effects of Eucalyptus............................................. 23

4. Economic Incentives for Tree Planting …………................................................ 24

Factor Input Markets—Land, Labor and Materials.......................................... 27

Output Markets for Timber and Non-Timber Forest Produce ............................. 35

Discount Rates, Portfolio Diversification and Access to Credit .......................... 39

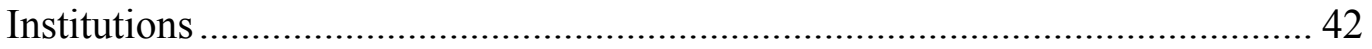

Discussion—Economic Incentives for Tree Planting ……………………….... 45

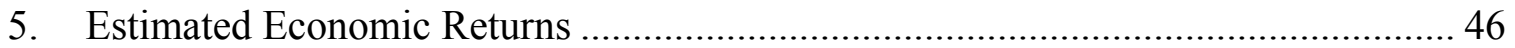

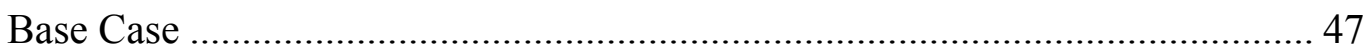

Impact of Different Harvest Periods .................................................................. 52

Impact of Crop Losses Due to Nutrient and Water Uptake by Eucalyptus.......... 54

Differences in Rates of Return Across Zones in Tigray ..................................... 56

6. Policy Options for Northern Ethiopia ………….................................................57

Promoting More Localized Woodlot Management............................................. 58

Allocate Portions or all of Existing Community Woodlots for Private

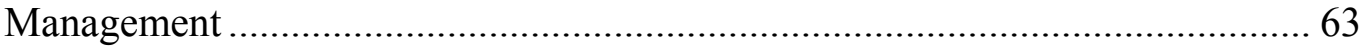

Increase Allocation of Hillsides and Degraded Lands for Private Tree Planting 66

Allow Eucalyptus Planting in Farmlands with Regulation ...................................6 68

Facilitate Access to Long-Term Credit and Other Factors

Favoring Tree Planting ........................................................................................ 70

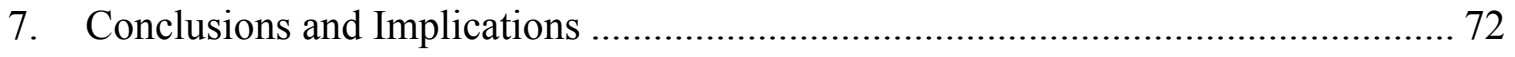

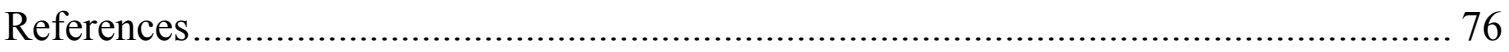




\title{
THE ROLE OF TREES FOR SUSTAINABLE MANAGEMENT OF LESS- FAVORED LANDS: THE CASE OF EUCALYPTUS IN ETHIOPIA
}

\author{
Pamela Jagger and John Pender*
}

\section{INTRODUCTION}

The combined effects of biomass shortages, soil and land degradation, overgrazing and increasing populations are hindering the success of sustainable agricultural systems in the Ethiopian highlands. Northern Ethiopia currently has very limited tree cover and the establishment of trees or other types of leafy ground cover that provide biomass fuel, environmental services including watershed management, soil nutrient and water retention, fodder for livestock, construction materials for rural smallholders, and a source of cash income, may increase the likelihood of Ethiopian smallholders achieving sustainable livelihoods. Forest policy that promotes various tree species and planting locations affects resource use and the sustainability of agricultural systems in the region in the medium-term as well as far into the future. Thus careful consideration should be afforded to what types of trees are promoted for planting in this region, as well as where and under what organization structure trees can be planted that will offer the greatest returns and environmental services to smallholders.

Currently the most common tree species for community woodlots and private tree investments in northern Ethiopia is eucalyptus. The planting of eucalyptus has a long history in Ethiopia dating back to extensive plantations surrounding urban centers in the late 1800s. However, it is only within the last 50 years that afforestation and reforestation with eucalyptus has been promoted and undertaken to any significant extent

*Pamela Jagger and John Pender are Research Analyst and Research Fellow, respectively, International Food Policy Research Institute, Washington, D.C. 
in rural areas. ${ }^{1}$ Although communities and more recently households that plant trees on community lands have exhibited a preference for eucalyptus, some regional governments have recently implemented a ban on the planting of eucalyptus trees on farmlands (Hagos, Pender, and Gebreselassie 1999). Restricting the planting of this fast growing species in a resource poor region may have significant implications for the rural poor with respect to access to woody biomass, forest resources, and opportunities for diversified income sources. On the other hand, eucalyptus are purported to have significant environmental costs associated with them. Trade-offs between potential socio-economic benefits and the environmental risks associated with planting these trees therefore need to be carefully evaluated.

In this paper we explore the controversial issue of eucalyptus tree planting in northern Ethiopia from both an ecological and economic perspective. The ecological considerations associated with planting eucalyptus are numerous and multifaceted. Issues such as increasing much needed biomass stocks and slowing soil erosion are important potential roles for fast growing tree species such as eucalyptus, particularly when trees are planted on wastelands with no alternative use. For example, as a consequence of deforestation and insufficient supplies of woody biomass, the use of alternative fuel sources - primarily manure and crop residues, has led to a decline or absence of critically needed organic fertilizers to support sustainable agricultural systems. The provision of significant woody biomass over the next 10-15 years by planting fast growing species such as eucalyptus could free up dung and crop residues for use in agricultural production.

Although eucalyptus may offer considerable benefits in terms of providing biomass and slowing erosion, concerns about negative impacts of eucalyptus on crop production has led to the ban on planting eucalyptus on lands where they may compete with crops. Often cited negative impacts include decreased crop output due to soil and

\footnotetext{
${ }^{1}$ We classify reforestation as the establishment of trees on a site that has been forested relatively recently, whereas afforestation is the establishment of tree cover on a site that has never been forested, or has not been forested for a very long period of time.
} 
water depletion. Although solid empirical evidence is scant, there is a perception in many regions of Ethiopia that eucalyptus has negative impacts on crops to the detriment of food security and livelihoods. The debate has pervaded the silviculture and social forestry literature during the past 30 years, and no consensus has been reached.

In addition to considering the ecological implications of planting trees in northern Ethiopia, the factors affecting whether or not tree-planting investments will be economically attractive to communities and smallholders are important to consider. Factors such as the opportunity cost of inputs including land, labor and materials, smallholder discount rates and the effectiveness of local organizations that manage woodlots are important to consider. For example, for poor households with high discount rates, tree-planting investments may only be attractive when benefits can be realized within 5 to 10 years of the initial investment. This has implications for the tree species that is promoted in the region and also whether or not trees should be planted on high potential land.

This paper provides a framework for discussion and policy recommendations concerning whether or not planting eucalyptus on farmlands and on other land types is a viable natural resource management technology to help achieve sustainable livelihoods in the Ethiopian highlands region. In addition to examining the ecological arguments surrounding the planting of eucalyptus in rural Ethiopia, we provide a discussion of the socioeconomic considerations facing rural smallholders and estimate ex ante returns to investment for tree growing, taking into account some of the ecological characteristics of this tree species under various conditions. Our goal is to provide a picture of the potential net benefit or cost to communities and smallholders of planting eucalyptus considering both ecological and economic parameters. Our analysis focuses on the Tigray region in northern Ethiopia, supported with socioeconomic data on eucalyptus tree growing in that region.

We consider four main questions: what are the ecological implications of limiting or promoting the planting of eucalyptus in different settings in the Ethiopian highlands, what are the economic incentives that motivate tree planting and the economic returns to 
planting eucalyptus in various settings; what are the potential economic returns to eucalyptus planting; and what short- and medium-term forest policy options may contribute to sustainable land use in the Ethiopian highlands region? After providing a brief historical overview of reforestation and afforestation in the Ethiopian highlands we summarize the current debate, both ecological and socioeconomic, surrounding the propagation of eucalyptus. Policy options ranging from increasing local authority to manage woodlots to intensive private tree planting on wastelands are considered.

\section{ETHIOPIA'S HISTORY OF REFORESTATION AND AFFORESTATION}

Eucalyptus was introduced to Ethiopia as early as the 1870 s through the establishment of block plantations surrounding the major cities to supply fuelwood for urban populations (Bristow 1995). ${ }^{2}$ By the mid-1970s, eucalyptus plantations owned by large landholders covered approximately 91,000 hectares in Addis Ababa and the surrounding highland towns (Henry 1973, as cited in Pohjonen and Pakulla 1990). Until the revolution in 1974, sources of forest products in rural areas were limited to natural forest exploitation with limited planting of eucalyptus on homesteads. After 1974, government policy shifted with respect to natural resource management. Agriculture and rural development moved to a more central point in the political agenda, the feudal system of land tenure was abolished, institutions such as Peasant Associations were developed to mobilize the rural population and administrations were set up to staff, finance, design and implement agriculture and forest policy (Poschen-Eiche 1987). This change facilitated the mobilization of rural resources to plant trees.

The introduction of rural afforestation and reforestation into government policy was motivated by several factors. The heavy reliance of increasing rural populations on natural forests and woodland for fuelwood and construction materials resulted in biomass

${ }^{2}$ Emperor Menelik II allowed the establishment of a trial plot of eucalyptus, and 15 species of eucalyptus were imported for trial in and around the capital city (Pohjonen and Pakulla 1990). 
shortages and required attention. Also, reforestation and afforestation were introduced as conservation tools to counteract the negative effects of deforestation on the environment. The role of trees in enhancing the sustainability of soil and water resources in rural areas was recognized and government programs were established to reforest severely eroded areas (Poschen-Eiche 1987). Finally, speculation that the highland region of Ethiopia was once covered in forest and was intensively cleared during the 1900's has motivated reforestation and afforestation efforts. The presence of remaining fragments of forest and woodland may indicate that the Ethiopian highlands were once covered in forest (Bristow 1995; Hoben 1996). However, this belief is poorly supported by data or historical account. ${ }^{3}$

From 1974 to 1984, the establishment of large-scale plantations declined due to revolution and land reform. The Derg's forestry policy strongly favored state and collective forestry, and actively discouraged individual tree planting (Bruce, Hoben and Rahmato 1994). Planting was facilitated through the Community Forestry Development Department (CFDD) of the Ministry of Agriculture, which operated on the philosophy that mass mobilization was the only way to achieve the Ethiopian target of self-reliance in production and supply of non-industrial wood products. From 1974 to 1991, the majority of rural afforestation took place in blocks of a few hectares, usually on hilltops, on workdays organized by Peasant Associations (Poschen-Eiche 1987). In addition to government initiatives, international support for rural afforestation with eucalyptus was provided by the Sudo-Sahelian Office of the UN (UNSO), which initiated a fuelwood program that established over 9000 ha of fuelwood plantations between 1984 and 1988 (Stiles, Pohjonen and Weber 1991). Also, since the mid-1980s, the African Development Fund and the World Bank have undertaken major plantation development projects, with Eucalyptus globulus being the main species promoted (Pohjonon and Pakulla 1990).

${ }^{3}$ See McCann (1995) for a presentation of reports of early travelers and explorers in Ethiopia and their perspectives on the proliferation of tree cover. 
Since the removal of the Derg from political power in 1991, one of the major shifts in Ethiopia's forest policy has been the encouragement of private tree planting. ${ }^{4}$ The challenges of collective tree planting make private tree planting a potential institutional option that may serve the dual purpose of conservation as well as a source of renewable fuelwood more efficiently than community tree planting, particularly on partitioned hillsides and commons (Bruce, Hoben and Rahmato 1994). Eucalyptus however has been at the forefront of the debate in this major institutional shift. In 1997, Tigray's administration enacted a new land policy that prohibits farmers from planting eucalyptus on cultivable land (Council of the National State of Tigray 1997). Ensuring that scarce farmland is used primarily for food production, as well as concerns about the ecological implications of eucalyptus for soil health, sustainability and crop output precipitated the legislation leading to the banning of eucalyptus planting on farmlands. However, empirical evidence to either support or refute the ecological impacts of eucalyptus in Ethiopia is scarce and the trade-offs associated with planting these trees should be evaluated in the broader context of land use management and household land use portfolios.

\section{THE ECOLOGICAL DEBATE}

The following is a summary of the continually broadening and persistently divisive debate in the literature that addresses the ecological effects of planting eucalyptus. The question of whether or not eucalyptus is appropriate for use on farmlands or on degraded lands with no other productive use has not been clearly answered in the literature. Generally speaking, studies focus on single issues rather than comprehensive environmental systems, and the majority of evidence provided is site

\footnotetext{
${ }^{4}$ A significant increase in tree planting on individually controlled land was noted by NGO workers in central and southern Ethiopia in 1990-91, immediately after the Derg abandoned key features of the agrarian reform program and relaxed control over the private sector (Hoben 1996).
} 
specific, discouraging extrapolation to regions with different environmental conditions. We emphasize that no single fact should be taken as sufficient evidence to promote or discourage the planting of eucalyptus, though the results from a large number of studies taken together may yield useful insights and generalizations.

We have identified what we feel are the key arguments in the eucalyptus debate to be considered in the context of the Ethiopian highlands region. Table 1 provides a summary of the major issues and briefly discusses the arguments pertaining to each point.

\section{PROVISION OF BIOMASS AND MAINTENANCE OF EXISTING FOREST COVER}

In Ethiopia, demand for woody biomass as an alternative to burning dung and crop residues is critical and requires a short-term solution if soil degradation is to be slowed. Approximately $95 \%$ of total demand for wood and woody biomass in rural Ethiopia is for fuelwood (EFAP 1993). ${ }^{5}$ With Ethiopia's remaining forest and woodland cover estimated to be diminishing at a rate of 50000 to 200000 hectares per year, the need to increase biomass by significant volumes in the near future is critical. ${ }^{6}$ In northern Ethiopia, dung and crop residues account for as much as $81 \%$ of total household energy consumption, leaving little organic matter for the fertilization of crops and causing soil degradation and accelerated erosion (Bekele-Tesemma, 1997). ${ }^{7}$ Although grasses and shrub type plants contribute to net biomass, trees are generally acknowledged to most efficiently convert deep soil nutrients and water into biomass. In severely stressed biomass deficit regions, fast growing tree species such as Eucalyptus globulus, E.

\footnotetext{
${ }^{5}$ Total demand for woody biomass was estimated at approximately 47.5 million $\mathrm{m}^{3}$ per annum in 1993 (EFAP 1993).

${ }^{6}$ Projections taking into account total remaining forest area and biomass density, combined with estimates of per capita biomass requirements suggest that by 2015 Ethiopia's indigenous woodland may be completely exhausted (Stiles, Pohjonen and Weber 1991).

${ }^{7}$ Burning of dung and crop residues currently represents an estimated loss in crop production equivalent to approximately 700,000 tons of grain per annum, and 20,00030,000 hectares per year of cropland are abandoned because soils can no longer sustain cropping (EFAP 1993).
} 
camaldulensis and E. saligna may be planted to produce high volumes of biomass within a short time frame. E. globulus for example, produces a harvestable tree crop in some

Table 1 Ecological effects of eucalyptus, summary

\begin{tabular}{|c|c|c|}
\hline Effect & Positive & Negative \\
\hline Biomass production & $\begin{array}{l}\text { Planting fast growing eucalyptus } \\
\text { may be one of the best short- } \\
\text { term options for the provision of } \\
\text { critically required biomass. }\end{array}$ & $\begin{array}{l}\text { Land scarcity may be a constraint } \\
\text { to wide-scale tree planting, } \\
\text { however wasteland and degraded } \\
\text { land is in good supply. }\end{array}$ \\
\hline $\begin{array}{l}\text { Effects on soils, } \\
\text { nutrient depletion } \\
\text { and topsoil retention }\end{array}$ & $\begin{array}{l}\text { On degraded hillsides and } \\
\text { wastelands the net soil nutrient } \\
\text { contribution of eucalyptus } \\
\text { through leaf litter is likely to be } \\
\text { positive. } \\
\text { - Good potential for topsoil } \\
\text { retention on degraded hillsides. }\end{array}$ & $\begin{array}{l}\text { Eucalyptus trees deplete soil } \\
\text { nutrients needed by agricultural } \\
\text { crops, however the spatial } \\
\text { magnitude of depletion is not } \\
\text { known. } \\
\text { - The ability of eucalyptus to } \\
\text { provide organic matter is } \\
\text { questionable. }\end{array}$ \\
\hline Allelopathic effects & $\begin{array}{l}\text { Rainfall may decrease or negate } \\
\text { the allelopathic effects of trees } \\
\text { on crops. }\end{array}$ & $\begin{array}{l}\text { - Allelochemicals negatively } \\
\text { influence agricultural production } \\
\text { and are a more significant factor in } \\
\text { dry regions. }\end{array}$ \\
\hline Hydrological impacts & $\begin{array}{l}\text { In regions with erratic and } \\
\text { severe rainfall the ability to take } \\
\text { up large quantities of water may } \\
\text { reduce runoff, flooding and } \\
\text { water logging } \\
\text { On previously barren slopes, } \\
\text { tree cover may reduce erosion } \\
\text { and gully formation caused by } \\
\text { rainfall. }\end{array}$ & $\begin{array}{l}\text { Eucalyptus may compete water } \\
\text { away from agricultural crops } \\
\text { decreasing agricultural output as } \\
\text { far as } 10 \text { meters away from where } \\
\text { trees are planted. } \\
\text { - Wide scale hydrological impacts } \\
\text { are uncertain. }\end{array}$ \\
\hline $\begin{array}{l}\text { Resistance to pests, } \\
\text { pathogens and } \\
\text { random disturbances }\end{array}$ & $\begin{array}{l}\text { - Some species of eucalyptus have } \\
\text { avoided attack from some } \\
\text { commonly observed insect pests } \\
\text { and are unpalatable to livestock. } \\
\text { - Some species are drought, flood } \\
\text { and fire resistant. }\end{array}$ & $\begin{array}{l}\text { Pests and pathogens may migrate } \\
\text { to unaffected regions causing } \\
\text { medium-term losses. } \\
\text { Non-palatability of leaves to } \\
\text { livestock is problematic for } \\
\text { farmers who require livestock } \\
\text { fodder. }\end{array}$ \\
\hline
\end{tabular}


regions within 5-6 years after planting, although the rotation age that maximizes wood production is approximately 18 years (Pohjonen and Pakkula 1990).

Species trials have been conducted in the Ethiopian highland region to determine which species - either indigenous or exotic, yield the highest mean annual increment (MAI), an indicator of volume and biomass productivity over time. ${ }^{8}$ In a 1975 trial conducted in Ethiopia's central plateau, results indicated that if the average 10-year growth of the best four eucalyptus species-E. globulus, E. salinga, E. grandis, W. Hill ex Maid, and E. vininalis Labill. is characterized by $100 \%$, the corresponding percentages for the four best exotic conifers and indigenous species were 55\% and 18\%, respectively (Pohjonen and Pukkala 1990). Estimates of MAI in Ethiopian eucalyptus woodlots range from approximately $10 \mathrm{~m}^{3} /$ ha/annum on poor sites (Newcombe 1989; Pohjonen and Pukkala 1990), to $57 \mathrm{~m}^{3} /$ ha/annum on more productive sites (Stiles, Pohjonen and Weber 1991). ${ }^{9}$ Estimates for other commonly observed coniferous plantations species range from $4.2 \mathrm{~m}^{3} / \mathrm{ha} /$ annum on low potential sites to $9.6 \mathrm{~m}^{3} /$ ha/annum on high potential sites. The mean annual increment associated with natural woodland is approximately 1.2 $\mathrm{m}^{3} /$ ha/annum (EFAP 1993). Given these estimates, the data indicate that for Ethiopia, under most conditions, eucalyptus is clearly the tree species that will most efficiently convert energy and available water into biomass.

Rapid growth rates in eucalyptus can be attributed to indefinite shoots (i.e., a growing tip that produces pairs of leaves at irregular intervals), and the fact that they do not develop resting buds. Given these characteristics eucalyptus can grow both in height and length indefinitely under favorable conditions. Further, when a branch or shoot is damaged the 'naked bud' - another growing tip, which can immediately produce a branch of the next order, quickly becomes a main bud. As the upper crown increases in height,

\footnotetext{
${ }^{8}$ Mean annual increment (MAI) is the estimated volume per hectare $\left(\mathrm{m}^{3} / \mathrm{ha}\right)$ divided by the age of the stand of trees.

${ }^{9}$ It should be noted that the expectation is that the majority of eucalyptus will be planted on poor land where the expected yield will be between 10 and $20 \mathrm{~m}^{3} / \mathrm{ha} /$ year (Pohjonen and Pakkula 1990).
} 
the lower parts of the trunk are built up very rapidly producing large volumes of wood per hectare (FAO 1979).

Although the planting of fast growing exotic tree species appears to offer an efficient and cost effective solution to Ethiopia's woody biomass crisis, the volume of wood required in the short-term is significant. If current per capita energy consumption remains constant (estimated at approximately $0.75 \mathrm{~m}^{3}$ per capita), the equivalent more than 2 million hectares of block plantations, producing $15 \mathrm{~m}^{3} /$ ha/annum (almost 10 times that which is currently established in industrial, peri-urban and community woodlots) are required to meet current demand, and six million ha of block plantations will be required by 2014 (EFAP 1993). Tree planting on this scale would occupy $6 \%$ of the total utilizable land area in Ethiopia, requiring a major land use shift (Böjo and Cassells 1995).

Although eucalyptus tree growing offers significant potential for biomass production, two complementary environmental policies should be consideredpreservation of existing woodland, and the concurrent promotion of planting indigenous tree species. Increasing biomass through the propagation of fast growing exotic species such as eucalyptus for construction poles and fuelwood should lead to the preservation of existing indigenous woodland. The establishment of woodlots and plantations to satisfy demand for forest produce has long been advocated as a strategy for relieving pressure on indigenous forest and woodland (Sedjo 1983; Tiarks, Nambiar, and Cossalter 1998.) ${ }^{10}$

Further, there is evidence suggesting that indigenous species such as Juniperus procera and Podocarpus gracilior may easily regenerate under some species of eucalyptus. For example, if there are indigenous seed trees in the vicinity - and if grazing is prohibited, indigenous species have regenerated under E. globulus. Once demand for biomass is met and pressure to cut indigenous woodland reduced, a partial

${ }^{10}$ Indigenous species including Olea africana, Acacia abyssinica and Juniperus procera are found only in small numbers, and at high elevations. Afro-alpine vegetation with species such as Erica arborea and Lobelia rhynchopetalum are increasingly scarce (Stiles, Pohjonen and Weber, 1991). 
restoration of indigenous forests could occur in the $4^{\text {th }}$ or $5^{\text {th }}$ rotation of the eucalyptus woodlot (Pohjonen and Pukkala 1990)

\section{EFFECTS ON SOILS: NUTRIENT DEPLETION, MOISTURE AND TOPSOIL RETENTION}

Up to half of arable land in the Ethiopian highlands is estimated to be moderately to severely eroded, and previously cultivable lands are being (or have been) turned to wasteland as a result of gully formation and loss of topsoil (FAO 1986; REST 1995). ${ }^{11}$ Planting trees can return nutrients such as nitrogen and potassium to the soil, and reestablishment vegetative cover to slow the effects of erosion from irregular and severe rainfall. Estimates of economic losses attributable to soil erosion were approximately EB 10-12 million per annum (calculated to 1994 prices) (Böjo and Cassells, 1994; Sutcliffe, 1993). ${ }^{12}$ Another estimate suggests that losses to agricultural production attributable to soil erosion, are estimated to be a cost to the Ethiopian economy of between $\$ 15$ million USD and \$1250 million USD (gross discounted cumulative loss), resulting in reducing farm incomes as much as 5 to 30\% by 2010 (Kappel 1996, as cited in FAO 1998).

When considering tree species to be used for afforestation or for integration into farming systems (i.e., agroforestry), depletion of soil nutrients is one of the most commonly cited criticisms associated with eucalyptus trees. In contrast to other commonly used afforestation and agroforestry species such as leucaena and acacia, eucalyptus are non-leguminous - they do not fix nitrogen, an essential element for soil health and sustainability. ${ }^{13}$ This characteristic is of greatest consequence when trees are

${ }^{11}$ It is estimated that currently 2 million ha of farmland have been irreversibly degraded, and by 2010 as many as 7.6 million ha of farmland will have deteriorated to the same status (FAO 1998).

${ }^{12}$ EB=Ethiopian Birr. Approximately EB6=US\$1 in April 1994 (Böjo and Cassells 1994).

${ }^{13}$ Leguminous plants bear nodules on the roots than contain nitrogen-fixing bacteria. Leguminous trees and shrubs use their extensive root systems to absorb substantial quantities of nutrients from lower soil horizons and enrich the topsoil through leaf litter (Verinumbe 1987). 
planted adjacent to agricultural crops. Advocates of agroforestry often cite the fact that leguminous trees contribute nitrogen to soils, enhancing crop productivity and sustainability. In contrast, non-leguminous trees such as eucalyptus may out-compete agricultural crops for scarce soil nutrients.

Evidence of soil nutrient depletion is inherently site specific, highly dependent upon the tree and crop interaction being considered, and the soil type under which the tree and food crop are established. There is significant support in the literature for the assertion that all fast growing tree crops deplete the nutrients on a site, regardless of whether or not the trees are leguminous (FAO 1985). To address this hypothesis, several studies have been conducted to compare tree and agricultural crop interactions.

Studies from various regions in sub-Saharan Africa provide evidence of the negative impacts of exotic tree crops on agricultural production. Verinumbe (1987), in a case study from Nigeria examined yields of maize, sorghum and groundnuts planted in pots with composite soil samples from three 12-year old exotic tree plantations - neem, prosopis, E. camaldulensis, and a control (where the control consisted of mixed surface soil from outside and adjacent to plantations). After 60 days of growth, results indicated that yields of maize and sorghum were highest under neem, whereas groundnuts - which are leguminous, produced high yields under the control and prosopis. For the three agricultural crops studied, the mean crop yield under neem, prosopis, eucalyptus and control were $13.99,8.32,6.80$ and $4.76 \mathrm{~g}$ /plant, respectively. The data suggest that although eucalyptus soils are superior to the control, they do not lead to strong crop growth even when a leguminous agricultural crop is planted.

Sanginga and Swift (1992) compared maize growth on indigenous miombo woodland soils with E. grandis soils in Zimbabwe. Greenhouse experiments indicated for the first crop of maize planted in E. grandis soils with eucalyptus leaf litter at the equivalent of $5 \mathrm{t}$ per ha, that shoot dry weight was reduced by $68 \%$. However, in the second crop rotation, shoot dry weight was positively correlated with increases in $E$. grandis leaf litter (a 97\% increase in shoot dry weight was observed when the equivalent of 5 tons per ha was applied to the experimental plot). Field results comparing 
eucalyptus and miombo woodland soils indicated that $\mathrm{K}$ and $\mathrm{Mg}$ were lower on eucalyptus sites, and that the best crop yields would be achieved if potassium and magnesium are supplemented through fertilization of eucalyptus soils, likely at a minimum rate of approximately $50 \mathrm{~kg} / \mathrm{ha}$. These findings suggest that eucalyptus should not be completely dismissed for use in agroforestry, particularly when fertilizer application is considered as a major input to the production process.

Michelsen, Lisanework, and Friis (1993) provide empirical evidence for soil nutrient depletion by exotic tree species in Ethiopia. Plots of dimension $10 \times 10 \mathrm{~m}$ of cupressus and E. globulus are compared with indigenous juniper and natural forest soils. Soils of cupressus and E. globulus were generally found to have the lowest nutrient content (mainly low in phosphorus and nitrogen), although herbaceous plants were important providers of nutrients in all sites. ${ }^{14}$ Indigenous woodland (i.e., juniper and natural forest soils) provided much higher nitrogen and phosphorus content in above ground herbaceous plants, indicating that nutrient cycling in sites dominated by exotic tree species is more constrained. Bioassay results indicated that low soil uptake of phosphorus, calcium and potassium was likely the factor limiting growth in agricultural crops such as Eragtrostis tef in eucalyptus soils. ${ }^{15}$

Although there is ample evidence of eucalyptus depleting soil nutrients, there is also evidence in the literature to suggest that eucalyptus may enhance some soil conditions, including moisture and topsoil retention, particularly on degraded or barren sites. It is generally accepted that the removal of vegetative cover, particularly trees, leads to increased surface run off and a subsequent increase in soil erosion. The prevalence of soil erosion causes loss of topsoil and rooting anchorage, loss of soil nutrients and breaching of the nutrient cycle, reduced water holding capacity and gully

${ }^{14}$ Herbaceous plants include forbes - for example broad leaf such as clover-and graminoids, which are narrowleaf grass-like plants that are not grasses according to taxonomic definition (Choudhury and Jansen 1998).

${ }^{15}$ Bioassay is a test that assesses the relative strength of a substance by comparing its effect on a test organism with that of a standard preparation. 
formation. These factors may collectively precipitate reduced agricultural productivity and an eventual and potentially irreversible shift to unproductive land often characterized as wasteland. Figure 1 summarizes the effect that the absence or removal of vegetative cover has on soil and moisture quality.

Tree planting is a natural resource management technology for improving the capacity of soil to retain water and also for enhancing soil nutrients. In general, trees improve ground cover, add organic matter to the soil, reduce the erosive impact of falling rain and improve infiltration of water into the soil. However, not all tree species function in the same manner, and choice of tree species - whether considering agroforestry, smallscale woodlots on arable land or plantations on degraded land - is an important decision.

Loss of topsoil moisture is a major concern on farmlands in semi-arid and drought prone areas. Trees planted as windbreaks or shelterbelts can facilitate topsoil moisture retention by retaining surface ground water for water recharge, reducing erosion, regulating flow, enhancing infiltration, reducing transpiration, improving water drainage systems and providing shelter from blown sand, drying winds, high temperatures and intense rainfall (Anderson 1987; FAO 1985; Stiles, Pohjonen, and Weber 1991). It is well documented that trees slow down the movement of both water and wind, allowing soil particles to remain or be deposited in cropping fields (Huchu and Sithole 1993).

Rainfall-induced erosion is a serious problem in the Ethiopian highlands that is exacerbated by the removal or absence of vegetative cover. Perennial vegetation such as trees may protect soils from rainfall erosion year round. The ability of eucalyptus to periodically take up high volumes of water (discussed later in this section), combined with the hydrological services that trees and tree roots perform — such as regulating sediment delivery, increasing water yield as runoff or sub ground flows and regulating the water table - may reduce the erosive effects of rainfall.

In addition to providing protection from wind and rain, trees reduce topsoil losses by adding organic matter to soil, improving ground cover and increasing soil stability through root formation. In some regions of Ethiopia, it is suggested that a $1 \%$ increase in organic matter can lead to a $15 \%$ decrease in erodibility (EFAP 1993). Species such as $E$. 
Figure 1 Likely hydrological changes following loss of vegetative cover

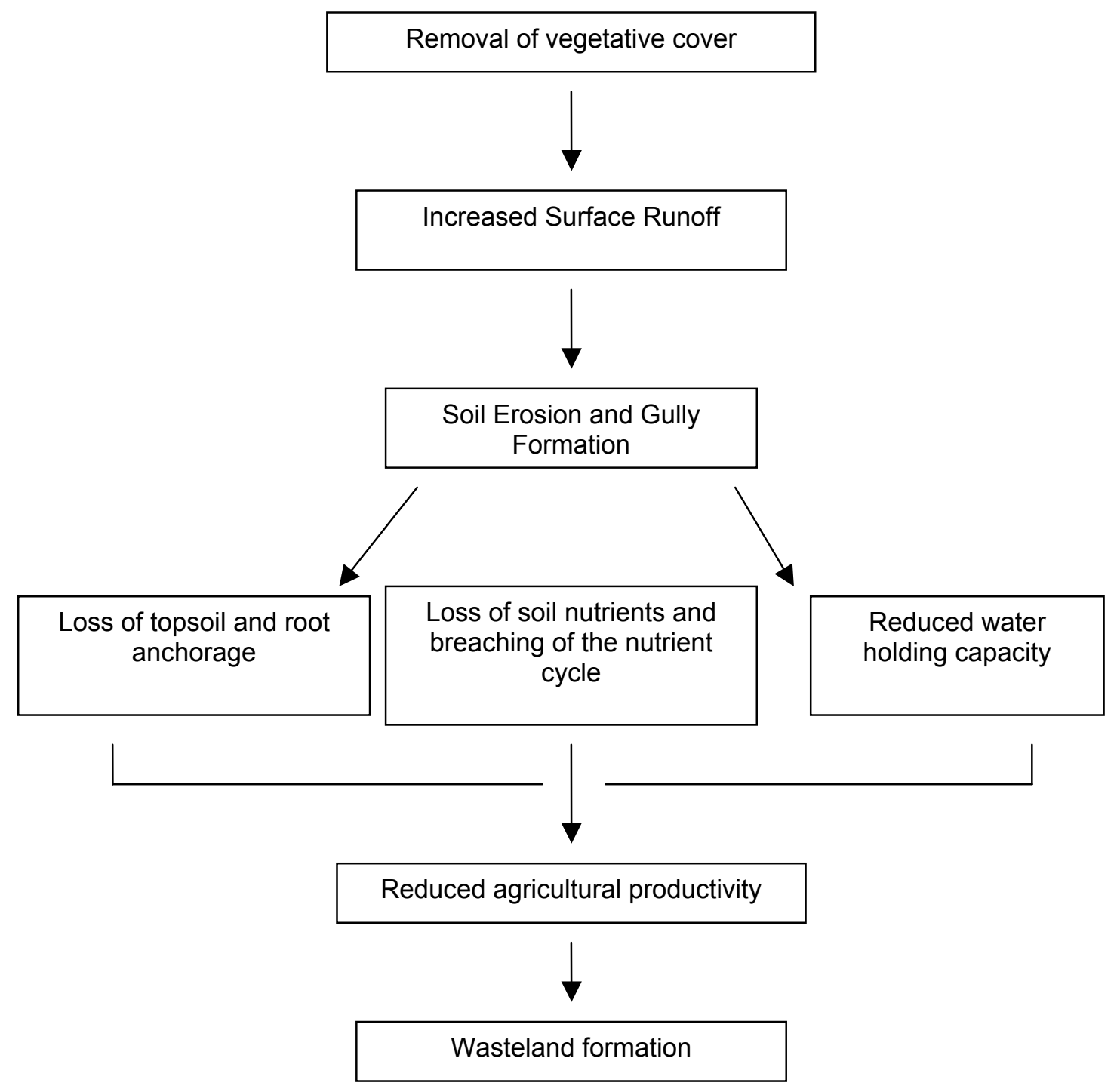

Source: Adapted from Cassells, Bonell, Hamilton, and Gilmour 1987. 
globulus are often noted as having relatively low levels of leaf litter build up, leaving little potential for erosion slowing if leaf litter is required to compensate for the absence of understory plants. However, there is evidence to suggest that after planting eucalyptus on previously treeless sites, soil fertility increases through development of mull humus, which may be slightly acidic on some soils (FAO 1985). Also, tree root systems contribute to soil strength by providing additional soil cohesion and reducing or halting mass wastage of slopes (Böjo and Cassels 1995).

The Ethiopian highlands are characterized by steep slopes and highly degraded surfaces, therefore trees may play a crucial role in ensuring that surface erosion is limited. Table 2 illustrates the relationship between land cover and erosion for various tree-cover scenarios.

Table 2 Relation between land cover and erosion (tons per ha per year)

\begin{tabular}{lccc}
\hline & \multicolumn{3}{c}{ Surface erosion } \\
\cline { 2 - 4 } Type of land cover & Minimum & Median & Maximum \\
\hline Natural forest & 0.03 & 0.3 & 6.2 \\
Shifting cultivation, fallow period & 0.05 & 0.2 & 7.4 \\
Forest plantation, undisturbed & 0.02 & 0.6 & 6.2 \\
Agriculture intercropped in young & 0.6 & 5.2 & 17.4 \\
forest plantation & 1.2 & 48 & 183 \\
Tree crops, clean-weeded & 5.9 & 53 & 105 \\
$\begin{array}{l}\text { Forest plantations, litter removed } \\
\text { or burned }\end{array}$ & & \\
\hline $\begin{array}{l}\text { a Refers to forests for timber production rather than tree crops. } \\
\text { Source: Weirsum (1984), reproduced from Bruijnzeel (1990), p.117. }\end{array}$
\end{tabular}

Evidence from the literature suggests that there is potential for eucalyptus to reduce topsoil runoff and slow erosion. For example, Grewal, Mittal, Dyal and Agnihotri (1992) found that there is potential for eucalyptus to reduce the rate at which wastelands are being formed. Their study in northern India, in a region topographically and 
climatically similar to the northern Ethiopian highlands, examined rain fed valleys and degraded forests on hill slopes focusing on silvopastoral systems (i.e., nursery raised $E$. tereticornis on sand loam soils with Bhabbar grass for pulp and grazing as lower canopy). Their findings indicate that most rainfall was conserved by the system, and that there was negligible water run off and soil loss; relative to bare land the silvopastoral system was superior and resulted in greater water retention and reductions in topsoil losses. In an Ethiopian context, Pohjonen and Pakkula (1990) acknowledge that eucalyptus may excessively use soil nutrients. However, they argue that this does not apply to the afforestation of bare highland sites, where the presence of eucalyptus is positive when compared with the prior barren state of sites.

\section{ALLELOPATHY}

Discussion of the significance of the allelopathic effects of eucalyptus pervades the agroforestry literature (May and Ash 1990). Allelopathy is the provision of chemicals from leaves or litter that inhibits the germination or growth of other plant species (FAO 1985). ${ }^{16}$ Reduction in crop output is the major implication of allelopathic effects in smallholder farming systems when trees are planted adjacent to crops. The long-term ecological consequences of allelopathic tree species on soils are not known. However, it has been hypothesized that long term exposure to allelochemicals may result in exposure of the soil to erosion, which may have implications for sustainable land use over time.

Scientifically rigorous studies examining the potential allelopathic effects of eucalyptus, and how far reaching those effects are in a spatial sense, are few. Sanginga and Swift (1992) use greenhouse and field experiments to examine the effects of $E$.

${ }^{16}$ For example, terpenoids, which are isometric hydrocarbons common to tree species that produce essential oils, resins or balsam, have been identified as allelopathic agents in E. globulus and E. camaldulensis, two of the commonly observed tree species in Ethiopia (Lisanework and Michelsen 1993). 
camaldulensis and E. grandis on maize germination, nutrition and growth of maize in Zimbabwe. Results suggest that germination of maize under eucalyptus leaf litter was dependent upon the quantity of leaf litter applied to the experimental plot, and that there is evidence of a positive 'fertilizer effect', from decomposing leaf litter. Field trials compared sites planted with eucalyptus and indigenous miombo woodland, and concluded that although significant variation in soil mineral content was observed (i.e., depleted magnesium and potassium in eucalyptus soils), there was little evidence to indicate that allelopathic effects were significantly inhibiting maize growth.

Lisanework and Michelsen (1993) provide an example of allelopathic evidence from Ethiopia by testing the effect of Cupressus lusitanica, E. globulus, E. camaldulensis and E. salinga on seed germination, radicle and seedling growth of four crops: chickpea, maize, pea and teff. Bioassay results indicate that all of the tested tree species significantly reduced germination in chickpea and teff, and growth in teff, and that the observed allelopathic effects were most significant under $E$. camaldulensis and $E$. salinga. The results of this particular study indicate the importance of considering interactions between tree species and agricultural crops if two species are to be planted in the same cropping system and suggests that E. globulus may be preferable, at least in terms of minimizing allelopathic effects.

Although there is sufficient evidence to indicate negative effects on crops due to allelopathy, the magnitude of these effects may be influenced by rainfall. It is likely that allelochemicals do accumulate in soil, however, these chemicals are highly soluble and rainfall is likely to leach them out of the soil surface (May and Ash 1990). Thus the effects of allelopathy are likely negatively correlated with rainfall. Malik and Sharma (1990) note that allelopathic effects are more severe in low rainfall regions prone to soil erosion. This has significant implications when taken in the context of the Ethiopian highlands, which are characterized by erratic rainfall and highly erosive soils. ${ }^{17}$

${ }^{17}$ In regions with low incidence of rainfall events, insufficient to cause runoff or deep drainage, allelochemical concentrations are maximized and there is the greatest potential for decreased crop output due to allelopathy (May and Ash 1990). 


\section{HYDROLOGICAL IMPACTS}

In addition to soil nutrient depletion and allelopathic effects, competition for water, generally to the detriment of neighboring plant species, depletion of the water table, and effects on the hydrological cycle are commonly cited arguments against the planting of eucalyptus. However, although anecdotal evidence is abundant, few empirical studies address the issue of water use by eucalyptus and its' direct effect on adjacent crop output. The general hypothesis is that high water requirements and characteristics such as deep root systems provide eucalyptus with a comparative advantage over other plants with respect to water usage. This is particularly serious when eucalyptus trees are planted in regions prone to drought conditions as the trees may cause drying of soil and water sources. However, the ability to tap water sources that other crops cannot, may allow for the provision of much needed income when food crops are destroyed.

Malik and Sharma (1990) assess the impact of eucalyptus on water uptake by agricultural crops in Haryana, India. By studying profile water, soil temperature and pan evaporation on the north and south sides of a row of E. tereticornis, and combining these data with crop output from adjacent plots with and without rows of eucalyptus, they conclude that grain yields of mustard and wheat decrease linearly with increasing moisture extraction. Further, eucalyptus extracted 5 times more water from the $0-150 \mathrm{~cm}$ profile as compared with mustard. From a distance of 10 meters away from the trees, a $47 \%$ reduction in mustard yield and $34 \%$ reduction in wheat yield was observed. The magnitude of these effects is relatively large and should be considered as a key argument against the planting of eucalyptus on farmlands, largely due to potential negative externality effects on smallholder crops as well as those of neighboring smallholders. Although the issue of allelopathy was addressed by the authors and found unimportant as a possible reason for reductions in crop output, soil nutrient depletion was not discussed as a possible contributing factor to the large reductions in crop output. The authors concluded that eucalyptus should not be row planted adjacent to crops in arid and semiarid regions with deep water table conditions. 
Saxena (1991) provides further support for intensive water use by eucalyptus in northwest India where farmers plant trees on farm bunds. Qualitative data indicate that farmers with trees close to water channels did not experience significant reductions in crop output. However farmers that were not close to water channels observed reductions in crop output after the first two years that persisted until the trees were harvested. Crop losses were estimated in economic terms. When crop losses were taken into account, benefit-cost ratios for tree planting dropped from 9 to just over 2, with crop losses being higher during winter months than during the summer monsoon, indicating excessive water use. Although planting eucalyptus indicates a significant decrease in returns, a benefit-cost ratio of 2 may justify the planting of eucalyptus in farming areas, even after crop losses are taken into account. ${ }^{18}$ Crop losses were higher during winter months than during the summer monsoon, indicating excessive water use.

Somewhat folkloric accounts suggest that eucalyptus trees have the capacity to affect domestic water supplies or irrigation reservoirs. However there is little empirical evidence to support this (FAO 1985). Not surprisingly, relative to grasses and shrubs, all tree species will decrease water yield. Whether or not eucalyptus reduces water yields more than other tree species is an open question. FAO (1985) suggests that a plantation of eucalyptus in any deforested catchment will substantially reduce water yield, but that the effect of decreasing water yield is probably less than that of pine and greater than other broad-leaved species.

Calder, Hall, and Prassana (1993) have examined the hydrological impacts of eucalyptus in India. Their results indicate that in some regions eucalyptus trees exhibited greater water use than recorded rainfall over the same time period, implying short to medium term water reductions. Their hypothesis is that a phenomenon known as "soil water mining" is occurring, whereby, the trees extensive root systems have been able to tap into water supplies other species are unable to reach. The implication of this is a justifiable.

${ }^{18}$ Any investment with a benefit-cost ratio above 1 is considered economically 
disturbance in the water table and potential draining of underground aquifers, which stabilize hydrological systems. However, conversely the ability of eucalyptus to take up significant quantities of water in short time periods that would otherwise be lost as runoff and/or contribute to flooding, indicating potential for use in floodplain management and crop salvage after intense rainfall.

\section{RESISTANCE TO DESTRUCTIVE PESTS, CLIMATE VARIABILITY AND OTHER RANDOM DISTURBANCES}

Insects, pathogens and livestock, as well as climate variability and random disturbances such as fire have significant impacts on herbaceous and woody plant species. The resistance of a tree species to destructive elements, as well as climatic shocks and events, significantly influences the rate of seedling survival and therefore the risk associated with investing scarce resources in planting a particular species.

A variety of insects are known to have a significant impact on eucalyptus including locusts, defoliating insects such as the eucalyptus snout beetle, sap suckers, bark beetles, wood borers and termites (FAO 1979). The influence that these pests have on tree survival is highly variable and depends upon the species planted and the climatic conditions affecting the region. In Ethiopia, all species of eucalyptus are susceptible to invasion by locusts; however, the eucalyptus snout beetle (weevil), known to destroy tree crops throughout east and southern Africa has not been observed in Ethiopia (Pohjonen and Pukkala 1990).

Termites are generally recognized as one of the most significant entomological threats to eucalyptus in sub-Saharan Africa (Atkinson, Nixon, and Shaw 1992). However, among the commonly planted species in Ethiopia, there is variability regarding how susceptible the trees are to attack; species such as E. camaldulensis are somewhat resistant to attack (Mazodze 1990). Further, intensity of termite attack varies with the age of the trees, soil type, and climatic conditions, including drought. Young trees are most open to attack by termites, as are trees planted in heavy soils, trees planted at low elevations and in low rainfall regions (FAO 1979). 
The major pathogen affecting eucalyptus is fungi, which may harm the roots, stems, leaves and the heartwood of the tree. Generally the effects of fungi are less significant at higher elevations, such as those observed in the highland region of Ethiopia. Further, fungi generally attack when trees are over mature, a characteristic that is seldom observed in woodlots where trees are being produced for subsistence timber and fuelwood (FAO 1979).

Livestock can cause considerable damage, especially to young trees. Although the allelochemicals produced in eucalyptus leaves are generally thought to make the leaves of eucalyptus unpalatable to livestock, goats and cattle will eat the leaves of some species such as E. camaldulensis. Interestingly, the leaves of E. globulus, the most commonly observed species of eucalyptus in Ethiopia, are unpalatable to cattle, sheep and goats (Pohjonen and Pakkula 1990).

To combat attacks from insects, fungi and livestock, eucalyptus trees possess accessory buds on terminal and axillary shoots that act as a replacement mechanism, regardless of the age of the tree (FAO 1979). Accessory buds produce new shoots from the leaf axil when buds and shoots above the axil are destroyed. The ability to rapidly produce new shoots after suffering substantial trauma increases the probability of survival, and gives eucalyptus comparative advantage over other tree species that do not possess similar characteristics.

Eucalyptus trees are recognized for their ability to adapt to both drought and flooding. In regions with erratic but intense rainfall, characterized by dry and sometimes drought conditions in intervening periods, eucalyptus trees may have a higher probability of surviving ecological disturbances than other tree species (Rocheleau, Weber, and Field-Juma 1988). For example, flooding has a positive impact on mean leaf area, and short term flooding is known to improve tree moisture status and increase growth rates (Bacon et al. 1993). When drought occurs, eucalyptus can tap deep-water sources with their roots. However, it is generally not until trees have been established for two to three years that they have developed extensive root systems that will allow them to survive droughts. Bacon et al. (1993), suggest that the roots of some eucalypts are known to 
extend as far down as 10 to 25 metres below ground surface, or 3-4 times the height of the tree, allowing the trees to access water that other plants are unable to utilize.

A final and beneficial characteristic of eucalyptus that bears particular relevance to drought prone regions is its ability to survive fire damage. Eucalyptus trees have anatomical organs in root collars that have dormant buds. When fire destroys the aerial parts of the tree, the buds sprout due to reserve foods in the protective organs (FAO 1979; Lacey 1974). As older plants have more elevated canopies (implying less tissue vulnerable to fire), and coppicing capacity (which increases with age), they are more likely to survive fires than younger plants (FAO 1979).

\section{DISCUSSION—THE ECOLOGICAL EFFECTS OF EUCALYPTUS}

The above discussion provides us with some valuable evidence but no definitive conclusions with respect to whether or not eucalyptus is an ecologically appropriate species for sustainable land management in the Ethiopian highlands. We emphasize the complexities associated with the factors that determine the ecological impact of eucalyptus trees both on adjacent crops as well as on soil and water conditions in general. Many of the studies we've presented above attempted to address ecological impacts in isolation. However, realistically both the positive and negative effects of eucalyptus on any given site are likely to be many and inter-related, making the question of the net effect of the tree crop on the site in question very complex.

Consider the case where a shelterbelt of E. camaldulensis is planted adjacent to a barley plot in the Ethiopian highlands, decreasing crop output in some defined area in close proximity to the trees. However, the benefits derived in terms of slowing erosion and retaining soil moisture over the entire plot of land may compensate for the losses in crop production experienced within the zone affected by the presence of the trees. Recall the benefit cost ratio for eucalyptus tree growing of 2.0 from a study in India cited earlier in this section indicating that even after accounting for crop losses, tree planting may still be beneficial to smallholders. It is important to consider net effects in cases such as this 
eucalyptus-barley system on a site-by-site basis, rather than negative or positive effects in isolation, before promoting or discouraging the planting of eucalyptus.

Whether or not the planting of eucalyptus is an ecologically favorable land use will also be highly dependent upon the environmental conditions that smallholders face. In regions where rainfall is sufficient to sustain trees, soil conditions are conducive to tree growth and perhaps less appropriate for food crops, and households have market access to inputs such as fertilizer, tree planting may be an environmentally sustainable land use alternative. We stress the site-specific nature of these alternatives, noting that in all likelihood there will be a high degree of variability within the Ethiopian highlands region.

\section{ECONOMIC INCENTIVES FOR TREE PLANTING}

In addition to ecological conditions, social and economic factors strongly influence smallholder land use decisions. Households determine their land use portfolios based upon potential net benefits given their environmental and economic resource endowments, and taking into consideration the time frame in which outputs will be profitable. These factors, including opportunity cost of the various factors of production, access to markets for inputs and outputs, transactions costs associated with institutions, risk and access to credit, and the discount rates of economic decision making units, need to be taken into account to identify locations economically as well as ecologically suited to growing eucalyptus.

In this section we discuss the various economic considerations influencing the decision to plant trees and establish a framework for ex ante cost-benefit estimates and sensitivity analysis of economic returns to community and private woodlots planted on communal lands in the Tigray region. ${ }^{19}$ To formulate cost-benefit estimates we rely on

${ }^{19}$ Note that data used for this analysis are preliminary and are intended to provide only a rough framework for ex ante benefit cost estimates. We are currently undertaking a targeted survey in Tigray and Amhara, Ethiopia focusing on community and private woodlots, and area enclosures that will provide us with more detailed data on tree growing. 
data collected during a survey of 50 tabias - the lowest administrative unit in Tigray, usually comprised of 4-5 villages - administered in the highlands of Tigray during the 1998-1999 cropping season. ${ }^{20}$ Tabias were selected based on a random sample, stratified by proximity to market town and the presence of an irrigation project. Within each tabia two villages were randomly selected. A questionnaire was administered with representatives of the community's farmers at both the tabia and kushet (village) levels, with each interview involving 10 respondents chosen to represent different age groups, primary occupations and gender (Gebremedhin, Pender and Tesfaye 1999). ${ }^{21}$

For the purpose of this analysis we distinguish between woodlots on community land that are managed by communities, and woodlots on community owned land that are privately managed by smallholders. ${ }^{22}$ Private tree planting on community-administered lands has been observed in recent years, particularly on hillsides and wastelands that have limited alternative uses. Of the fifty tabias in our sample, 46 have community woodlots. On average there are about 9 woodlots per tabia. Tabia councils manage approximately one-third of the woodlots, and all members of the tabia generally have the right to use the woodlot. All other community woodlots are managed at the village (kushet) level by village councils and are used only by the members of that village. Twenty-five percent of tabias have privately managed woodlots on community land.

Table 3 outlines the socioeconomic parameters we employ in our ex ante costbenefit estimates and summarizes how each of the various factors may influence economic returns to eucalyptus tree planting. Each point is then discussed in greater detail in this section.

${ }^{20}$ Highlands are defined as those areas above 1500 m.a.s.l.

${ }^{21}$ The administrative levels in Tigray are zones, woredas and tabias. There are presently four zones - southern, central, eastern and western-36 woredas, and 550 tabias in Tigray.

${ }^{22}$ The community survey did not investigate private tree planning on private lands. This is being examined in a household survey that is being conducted in 2000 . 


\section{Table 3 Benefit-cost parameters and possible factors influencing benefit-cost estimates}

\begin{tabular}{|c|c|c|}
\hline Benefit-cost criteria & $\begin{array}{l}\text { Conditions for positive economic } \\
\text { returns }\end{array}$ & $\begin{array}{l}\text { Conditions for negative economic } \\
\text { returns }\end{array}$ \\
\hline Land & $\begin{array}{l}\text { Land abundant (low population } \\
\text { densities) } \\
\text { - Low potential land, hillsides or } \\
\text { wasteland that have low or zero } \\
\text { opportunity cost } \\
\text { - Few negative environmental } \\
\text { externalities and/or positive } \\
\text { externalities }\end{array}$ & $\begin{array}{l}\text { Land scarce (high population } \\
\text { densities) } \\
\text { - High potential land with high } \\
\text { associated opportunity cost } \\
\text { - Significant negative } \\
\text { environmental externalities }\end{array}$ \\
\hline Labor & $\begin{array}{l}\text { Low to medium wage rates } \\
\text { (may be associated with high } \\
\text { population density distant from } \\
\text { off-farm labor markets) } \\
\text { High wage rates may also favor } \\
\text { tree planting when compared } \\
\text { with other labor intensive } \\
\text { activities }\end{array}$ & $\begin{array}{l}\text { High wage rates (may be } \\
\text { associated with low population } \\
\text { density relatively close to off- } \\
\text { farm labor markets) }\end{array}$ \\
\hline Material inputs & $\begin{array}{l}\text { Low cost material inputs related } \\
\text { to good access to input markets } \\
\text { Presence of NGOs and other } \\
\text { organizations that offer inputs } \\
\text { for free or at subsidized prices }\end{array}$ & $\begin{array}{l}\text { - High cost of material inputs } \\
\text { related to remoteness from } \\
\text { input markets } \\
\text { - Absence of NGOs and other } \\
\text { subsidizing agencies }\end{array}$ \\
\hline Output prices & $\begin{array}{l}\text { Good output market access } \\
\text { (may be partially related to } \\
\text { proximity to major road, } \\
\text { Woreda town and high } \\
\text { population density) } \\
\text { Markets with sufficiently elastic } \\
\text { demand }\end{array}$ & $\begin{array}{l}\text { Poor market access } \\
\text { (characteristic of poor access } \\
\text { to roads and towns) } \\
\text { - Inefficient markets and/or } \\
\text { inelastic demand }\end{array}$ \\
\hline Discount rates & $\begin{array}{l}\text { - } \text { Low discount rates } \\
\text { - } \text { Good access to credit markets } \\
\text { - } \text { High potential lands yield high } \\
\text { MAI providing returns in } \\
\text { shorter time horizon }\end{array}$ & $\begin{array}{l}\text { - High discount rates } \\
\text { - } \quad \text { Poor access to credit markets } \\
\text { - Low potential yields yield low } \\
\text { MAI providing returns in } \\
\text { medium to long run }\end{array}$ \\
\hline Institutional factors & $\begin{array}{l}\text { - Access to benefits not restricted } \\
\text { - Strong collective action }\end{array}$ & $\begin{array}{l}\text { - Restricted access to benefits } \\
\text { - Weak collective action }\end{array}$ \\
\hline
\end{tabular}




\section{FACTOR INPUT MARKETS—LAND, LABOR AND MATERIALS}

The cost of producing and bringing timber and non-timber forest products to market, or being able to employ them for household use or consumption is defined by the costs of land, labor and material inputs (Dewees and Saxena 1997a). We hypothesize that factors such as population density, proximity to towns, distance to all weather roads, and altitude may affect the value or opportunity cost of the three major factors of production for tree planting. Table 4 provides estimates of average population densities and distances to Woreda (district) towns, all weather roads, and altitude for sample tabias in the four administrative Zones of Tigray.

Table 4 Indicators of opportunity cost of factors of production, means ${ }^{\mathrm{a}}$

\begin{tabular}{lcccc}
\hline Zone & $\begin{array}{c}\text { Population density } \\
\text { (persons/sq km) }\end{array}$ & $\begin{array}{c}\text { Distance to } \\
\text { Woreda town } \\
(\mathrm{km})\end{array}$ & $\begin{array}{c}\text { Distance to nearest } \\
\text { all weather road } \\
(\mathrm{km})\end{array}$ & $\begin{array}{c}\text { Mean altitude } \\
\text { (m.a.s.1.) }\end{array}$ \\
\hline $\begin{array}{l}\text { Southern Zone } \\
(\mathrm{N}=14)\end{array}$ & 112 & 30 & 14 & 2194 \\
Central Zone & $(18.42)$ & $(6.62)$ & $(3.91)$ & $(139.94)$ \\
$(\mathrm{N}=17)$ & 170 & 27 & 15 & 2073 \\
Eastern Zone & $(26.71)$ & $(5.29)$ & $(3.55)$ & $(71.73)$ \\
(N=12) & 144 & 21 & 14 & 2091 \\
Western Zone & $(17.38)$ & $(9.30)$ & $(5.56)$ & $(67.74)$ \\
$(\mathrm{N}=7)$ & 70 & 20 & 8 & 1543 \\
Average & $(13.49)$ & $(6.25)$ & $(3.10)$ & $(59.47)$ \\
$(\mathrm{N}=50)$ & 132 & 26 & 14 & 2023 \\
\hline $\mathrm{a}$ Values & $(12.62)$ & $(3.39)$ & $(2.12)$ & $(59.88)$ \\
\hline
\end{tabular}

${ }^{\mathrm{a}}$ Values in parentheses are standard errors. All means and standard errors are corrected for sampling stratification and sampling weights.

${ }^{\mathrm{b}}$ Because the survey was conducted only in highland Woredas (i.e. $>1500$ m.a.s.1.), several lowland Woredas in the Western Zone were excluded.

The opportunity cost of land, (i.e., the rental value of land in its second most efficient use), may or may not be a major cost of production for tree planting on communal lands (Price 1989). The opportunity cost of land will likely be dependent 
upon three factors - how scarce land is, whether or not available land has high or low potential for other uses such as grazing livestock or planting food crops, and the extent of negative or positive environmental externalities associated with the land use. Land will be scarce where population densities are high and land is generally already occupied in its highest value use. For example, as Table 4 indicates, land is most scarce in the Central Zone of Tigray. Population densities in Tigray vary greatly by tabia, ranging from 32 persons per square $\mathrm{km}$ to just over 300 persons per square $\mathrm{km}$ with an average of approximately 132 persons per square $\mathrm{km}$.

In addition to scarcity, the productive capacity of land affects opportunity cost. Land will be a significant cost of tree planting when areas of medium or high potential land are taken out of their best alternative use. Conversely, marginal lands or wastelands with few or no other productive uses will have low or zero opportunity costs, making them more attractive sites for tree planting where trees are capable of growing. When trees are planted as plot boundaries, on household compounds or as living fences such that they occupy small previously unutilized areas, land may also have low or no opportunity cost (Gergersen, Draper, and Elz 1989). However, negative externalities due to possible negative impacts of eucalyptus on crop production may affect smallholders that plant trees on farmlands, or neighbors with plots adjacent to eucalyptus trees. Negative externalities are likely to be greatest in population dense settings characterized by small fragmented land holdings.

The opportunity cost of land can be estimated using returns to land from planting cereal crops. However, because such estimates only encompass farmlands, which is generally the land of highest potential, the per hectare estimates of land value provided in Table 5 represent a conservative upper limit on the opportunity cost of land. These estimates also overstate the opportunity cost of land because they represent gross rather 
than net profit per hectare. ${ }^{23}$ Table 5 summarizes the estimated gross value per hectare for several major cereal crops in 1998. Data indicate that the average gross value of farmland was approximately 840 Ethiopian Birr per hectare in 1998. ${ }^{24}$

Table 5 Gross value per hectare of major crops by zone, birr/ha, $1998^{\mathrm{a}}$

\begin{tabular}{lcccccccc}
\hline Zone & Barley & Maize & Wheat & Sorghum & $\begin{array}{c}\text { Finger } \\
\text { Millet }\end{array}$ & Teff & Millet $\begin{array}{c}\text { Weighted } \\
\text { Average, } \\
\text { All Crops }\end{array}$ \\
\hline $\begin{array}{l}\text { Average } \\
(\mathrm{N}=50)\end{array}$ & 905 & 576 & 870 & 819 & 1039 & 918 & 797 & 841 \\
& $(117)$ & $(140)$ & $(119)$ & $(112)$ & $(247)$ & $(175)$ & $(147)$ & \\
\hline
\end{tabular}

${ }^{\mathrm{a}}$ Values in parentheses are standard errors. All means and standard errors are corrected for sampling stratification and sampling weights.

The area of land used for tree planting varies between tabia and kushet community woodlots and woodlots managed privately by smallholders. Community woodlots managed at the tabia level average 18.5 ha while kushet managed woodlots are generally much smaller, averaging approximately 5 ha. Private woodlots on tabia land average approximately 5 hectares per woodlot, and private woodlots on kushetadministered lands are smaller at less than 2 hectares per woodlot. The majority of community woodlots are planted to more than one species, and some woodlots have 5 or more different stands of trees. ${ }^{25}$ Table 6 summarizes data for commonly observed tree species by stand and land area occupied for the both community and private woodlots on tabia and kushet administered lands.

${ }^{23}$ Data regarding the value of labor for crop production in Tigray were not available from community survey data. Secondary data on Tigray indicate that the value of labor per hectare for farmland averaged approximately 600 Birr/ha in 1995, indicating that net profits are much less than gross profits per hectare (UNDP/ECA 1994).

${ }^{24}$ Estimates of cropland rental value from our community survey are similar to the gross value per hectare estimates in Table 5.

${ }^{25}$ We define a stand of trees as all trees of the same species that are planted in the same calendar year. 
The data in Table 6 indicate that eucalyptus species are the most frequently observed trees in kushet woodlots, and illustrates the relatively high number of trees that are planted per stand. By assuming a standard planting density for all species, we can conclude from the data that the area planted to E. camaldulensis and E. globulus surpasses that of other species in both tabia and kushet woodlots. This indicates that the most significant tree planting investments are for eucalyptus. ${ }^{26}$ Eucalyptus stands are more frequently occurring for privately managed woodlots than for community woodlots. This suggests that other species of trees are being promoted in community woodlots whereas farmers that plant trees privately prefer eucalyptus trees. Data on the location of private plantings on community lands indicate that the $100 \%$ of E. globulus and E. camaldulensis plantings are on hillsides or wasteland rather than cultivated land. This suggests that private plantings on community land, because they are planted on low quality land with few other productive uses, have low or no opportunity cost associated with them.

Where the opportunity cost of land is low, labor is the primary input to production for tree planting. However, when compared with other land uses such as annual wheat production, the opportunity cost of labor for tree planting and management will be relatively low, particularly in years after the trees are established (Dewees and Saxena 1997a). The factors related to labor that will influence community or household level incentives to plant trees include population density, household demographics with respect to numbers of women and children that can assist with caring for trees, availability of

${ }^{26}$ It could be argued that the widespread adoption of eucalyptus is a function of seedling availability. Data indicating whether or not seedling supply was sufficient for all species is available for community woodlots. Tabia-managed woodlots cited the supply of seedlings as being sufficient for all species $100 \%$ of the time. Community woodlots administered at the kushet level cited shortages of seedlings for the following species, Acacia saligna, E. globulus, Dodnia augistifolia, and Acacia seyal at rates of $6 \%, 16 \%, 14 \%$ and $56 \%$ of stands planted to each species respectively. These data indicate that although seedling shortages are experienced with respect to some species, land planted to eucalyptus is likely mainly a function of community preference for the species. Data on seedling supply were not available for private plantings. 
High land-to-labor ratios, relatively high population densities fueled by a recent influx of farmers returning from resettlement areas, and refugees returning from Sudan suggest that there is likely a large labor force in Tigray and consequently generally low wage rates (Gebremedhin 1998). Although abundant labor suggests that labor is available for tree planting, there is also high labor demand for food crop production and raising livestock. Moderate population densities combined with relatively short distances to Woreda towns, as is the case for the Eastern Zone in Tigray, yields higher wage rates in this region (Table 7). As expected, where population densities are moderate and distances to towns with off-farm labor opportunities are relatively short, higher wage rates are observed.

Table 7 Average wage rates for Tigray by zone, 1998, birr/day

\begin{tabular}{lccc}
\hline Zone & Male wage rate & Female wage rate & Child wage rate \\
\hline $\begin{array}{l}\text { Southern } \\
(\mathrm{N}=14)\end{array}$ & 7.22 & 5.16 & 3.61 \\
& $(0.45)$ & $(0.42)$ & $(1.55)$ \\
Central & & & \\
$(\mathrm{N}=17)$ & 7.68 & 5.99 & 5.24 \\
& $(0.37)$ & $(0.48)$ & $(2.31)$ \\
Eastern & & & \\
$(\mathrm{N}=12)$ & 8.99 & 7.28 & 2.03 \\
& $(0.62)$ & $(0.64)$ & $(0.39)$ \\
Western & 6.62 & 5.52 & 4.49 \\
$(\mathrm{~N}=7)$ & $(0.66)$ & $(0.53)$ & $(1.86)$ \\
& & & \\
Average & 7.70 & 5.98 & 3.85 \\
$(\mathrm{~N}=50)$ & $(0.28)$ & $(0.30)$ & $(0.98)$ \\
& & & \\
\hline
\end{tabular}

\footnotetext{
${ }^{a}$ Values in parentheses are standard errors. All means and standard errors are corrected for sampling stratification and sampling weights.
}

Data for Tigray indicate that labor is the primary input to production for both tabia- and kushet-administered woodlots, particularly in the first three years after planting. Table 8 summarizes the number of labor days per hectare dedicated to various management tasks performed for tabia and kushet community woodlots in 1998. We note 
that labor estimates are for community woodlots based on woodlot level data rather than stand level data. This means that labor inputs for management tasks for a variety of species over the total area of the woodlot are represented below. Also, labor inputs for 1998 are for woodlots at various stages of development. The data in Table 8 are preliminary and not complete enough to draw significant conclusions regarding the management activities that communities are dedicating labor to. However, it is clear that significant labor investments are involved in planting trees in community woodlots. This finding indicates that labor investments in tree planting will be significant in the first year or two of woodlot establishment and are likely to diminish in years beyond. We also note that there is a higher intensity of labor use on a per hectare basis in kushet-managed woodlots.

\section{Table 8 Labor input by management task for tabia and kushet community woodlots, person days per hectare ${ }^{a, b}$}

\begin{tabular}{lcc}
\hline Labor activity & $\begin{array}{c}\text { Labor in tabia woodlots } \\
(\mathrm{n}=114)\end{array}$ & $\begin{array}{c}\text { Labor in kushet woodlots } \\
(\mathrm{n}=151)\end{array}$ \\
\hline Tree planting/Digging holes & 10 & 112 \\
& $(53)$ & $(489)$ \\
Soil and water conservation & 45 & 69 \\
practices & $(255)$ & $(317)$ \\
Cultivation/Harrowing & 32 & 24 \\
& $(336)$ & $(143)$ \\
$\begin{array}{l}\text { Estimated total labor days per } \\
\text { hectare }\end{array}$ & 87 & 386 \\
\hline
\end{tabular}

${ }^{a}$ Values in parentheses are standard errors. All means and standard errors are corrected for sampling stratification and sampling weights.

${ }^{\mathrm{b}}$ Over 50\% of tabia and kushet stands were established in 1997 or 1998 so these data should provide a relatively good indication of labor tasks in the first years of tree growing.

Finally we consider purchased material inputs such as seedlings, fencing materials and fertilizers. Seedlings are the primary input purchased for woodlots in the Ethiopian highlands. Use of other inputs such as fertilizer and pesticides (both organic and 
chemical) are not currently observed for tree production in Tigray. The cost of seedlings in Tigray is relatively low (i.e. seedlings generally cost 1 cent birr each or approximately $1 / 8$ of 1 US cent), and prices do not vary greatly across the region. However, factors such as the distance to Woreda town or all weather roads will influence the transactions costs associated with obtaining seedlings. Remote regions will generally have higher transactions costs associated with acquiring seedlings including traveling to the closest tree nursery and transporting seedlings.

Community woodlots benefit from subsidized or free inputs (mainly seedlings) that are provided by local extension agents, government nurseries or NGOs. There are currently three types of tree nurseries in Tigray, state, community and private. Community nurseries that receive material and technical support from Bureau of Agriculture and Natural Resource Development have been developed to decentralize seedlings distribution and reduce transportation costs (BoANRD 1996). State nurseries currently sell seedlings to farmers as well as providing seedlings for community woodlots. In Tigray the majority of seedlings for community woodlots are purchased or received from the Bureau of Agriculture (i.e., $90 \%$ of E. camaldulensis and E. globulus seedlings) or the Relief Society of Tigray (REST). In addition to state and community nurseries, individual farmers on a limited scale raise their own seedlings (Gebremedhin, Pender, and Tesfaye 2000).

The construction of fences to keep grazing livestock away from young trees and leaves and the use of inputs such as fertilizer are known to increase both the mean annual increment and survival rates of woodlots, providing higher economic returns in a shortened time horizon (Jagger 1999; Mandondo 1995). However, their use in community woodlots is limited due to the high opportunity costs associated with taking these scarce resources away from food crops. Other problems such as a lack of awareness of the potential benefits of management activities such as applying fertilizer to tree crops may also be limiting their use in community woodlots. 


\section{OUTPUT MARKETS FOR TIMBER AND NON-TIMBER FOREST PRODUCE}

Input availability and costs are only part of the equation that the smallholder considers when deciding to plant trees. Smallholders benefit from tree planting by producing timber and non-timber forest products for household consumption as well as for sale, and both subsistence use and the sale of forest products increases household incomes and improves livelihoods. Eucalyptus trees provide a range of timber and nontimber benefits to rural households in Ethiopia. Poles and fuelwood are the primary timber products produced and there are a wide range of other timber benefits that include branches, sticks and leaves for fodder, fuel, and charcoal production. Non-timber forest products include medicines, tannin and resin, and honey and beeswax (Jagger 1999; Rocheleau, Weber, and Field-Juma 1988). Potential non-market benefits include windbreak or shelterbelt values, ornamental values, shade and a variety of values associated with the environmental services discussed in the previous section such as soil stability and water filtration.

Both household demand and prevailing market conditions for timber and nontimber forest products influence the decision to plant trees, and the presence of efficiently functioning markets is important to increasing household incomes through the sale of forest products in the Ethiopian highlands. For example, if tree planting on wasteland is successfully promoted in a region that is currently experiencing relatively small excess demand for poles and fuelwood, when the trees are harvested there is the potential for market gluts that will drive down prices, possibly shifting cash returns from tree product sales from positive to negative (Dewees and Saxena 1997b; Saxena 1991). ${ }^{27}$

Little information is available regarding how robust, thin or stable the markets for timber and non-timber forest products are in rural Ethiopia. Markets for poles, fuelwood

${ }^{27}$ Saxena (1991) presents an example of a region in India that under the social forestry movement of the late 1970s and 1980s planted large areas of eucalyptus. When the trees were ready for harvest the influx of poles into the market caused a glut and farmers were unable to sell their tree stock. 
and to a much lesser extent charcoal are well developed close to Addis Ababa and other urban areas characterized by high population densities, extensive deforestation, reliable transportation infrastructure and high prices for substitutes such as kerosene (Newcombe 1989). ${ }^{28}$ In Tigray, woodlot products are sold within tabias and also in woreda towns. Eucalyptus is by far the most commonly marketed species with $51 \%, 63 \%$ and $74 \%$ of thin, medium and thick poles respectively being either E. camaldulensis or E. globulus. Eucalyptus poles are used mainly for construction purposes and farm implements, and are not observed being sold for fuelwood or furniture making. It is likely that when eucalyptus is used for fuel it is collected and consumed at the household level rather than sold, and that there are preferred hardwood species for furniture making such as Cordia africana. Table 9 summarizes prices for eucalyptus poles (EB/pole) in Woreda towns and tabias in $1998 .^{29}$

${ }^{28}$ It is interesting given biomass shortages in Ethiopia that the issue of charcoal production from plantation or woodlot species has not been widely explored. Eucalyptus wood makes good strong charcoal that is suitable for both domestic and commercial use (FAO 1985). The use of charcoal in Ethiopia is not commonly observed, possibly due to preferences toward fuels that provide quick intense heat for cooking the food staple injera. In 1990/91, consumption of charcoal was approximately 256,000 metric tons, compared with approximately 33,858,000,3,942,000 and 3,237,000 metric tons of woody biomass, dung and crop residues consumed, respectively (EFAP 1993). The main benefit of charcoal is that given an energy density per unit volume of about 1.9 times that of wood, it is much more efficient to transport and store than wood (Armitage and Schraum 1989). In countries with fuelwood deficits concentrated in heavily deforested population dense regions, the ability to efficiently transport charcoal from one region to another is a significant benefit.

${ }^{29}$ We did not find any significant difference in pole price between the two commonly observed species of eucalyptus aain Tigray. Therefore, the pole price data for E. camaldulensis and E.globulus have been aggregated to estimate average pole price for each Zone. 
Table 9 Average eucalyptus pole prices, EB/pole, $1998^{\mathrm{a}}$

\begin{tabular}{lcc}
\hline Zone & Woreda town & Tabia \\
\hline Southern & 25.01 & 25.90 \\
$(\mathrm{~N}=14)$ & $(6.75)$ & $(6.12)$ \\
Central & 33.83 & 41.12 \\
$(\mathrm{~N}=17)$ & $(7.76)$ & $(7.58)$ \\
& & \\
Eastern & 30.17 & 28.71 \\
$(\mathrm{~N}=12)$ & $(3.52)$ & $(2.66)$ \\
& & \\
Western & 16.59 & 20.91 \\
$(\mathrm{~N}=7)$ & $(3.12)$ & $(5.11)$ \\
Total Region & 31.14 & 28.43 \\
$(\mathrm{~N}=50)$ & $(3.32)$ & $(3.61)$
\end{tabular}

\footnotetext{
${ }^{\mathrm{a}}$ Values in parentheses are standard errors. All means and standard errors are corrected for sampling stratification and sampling weights.
}

We can consider the pole price data in Table 9 in the context of the population density and market access variables presented in Table 4. We expect that pole prices should be high where population density is highest due to high demand. Accordingly, poles prices should be high in the population dense Central Zone, as is the case in the above table. We also expect that where market access is good, the difference between tabia and woreda prices will be less.

It is likely that local or regional markets and trade in non-timber forest products derived from eucalyptus contribute to subsistence supplies and in some cases household incomes, but this varies greatly between regions. The most likely non-timber eucalyptus products for improving household incomes are honey and beeswax. The joint production of honey or beeswax with timber or fuelwood requires relatively low-input, low-cost technologies. Ethiopia ranks fourth in the world as an exporter of beeswax, and tenth in honey exports. If rural woodlot producers can gain access to this market, household incomes may increase (Bristow 1995). Survey data from Tigray indicate that community 
woodlots are already involved in beekeeping. Beekeeping is practiced in $42 \%$ of community managed tabia woodlots, and 53\% of kushet woodlots.

Another commonly observed benefit is the collection of grass from community woodlots for use as fodder. Grass is collected for household use and also for sale. Table 10 summarizes the proportion of households that collected grass in 1998 in both tabia and kushet managed woodlots as well as the average number of head loads of grass collected per hectare, the value per head load and the average gross total value of grass per hectare. Data indicate that a higher proportion of households for kushet managed community woodlots collects grass, and also that a greater quantities of grass are harvested from kushet managed woodlots.

Table 10 Grass collection in community woodlots, 1998

\begin{tabular}{lcc}
\hline & $\begin{array}{c}\text { Tabia-managed } \\
\text { woodlots }\end{array}$ & $\begin{array}{c}\text { Kushet-managed } \\
\text { woodlots }\end{array}$ \\
\hline Proportion of households that collect grass & 0.23 & 0.37 \\
& $(0.31)$ & $(0.08)$ \\
Average number of head loads collected per & 22 & 161 \\
hectare of woodlot 1998 & $(32)$ & $(494)$ \\
& & \\
Average price per head load (EB/Head load) & 7.08 & 5.85 \\
& $(1.65)$ & $(0.81)$ \\
Gross value of grass per hectare of woodlot, & 98 & 1134 \\
$1998^{\text {b }}$ & $(167)$ & $(2747)$ \\
\hline
\end{tabular}

${ }^{\mathrm{a}}$ Values in parentheses are standard errors. All means and standard errors are corrected for sampling stratification and sampling weights.

${ }^{\mathrm{b}}$ These estimates are for woodlots where grass was collected. Our data indicate that grass was collected in 50\% of tabia woodlots and $69 \%$ of kushet community woodlots. 


\section{DISCOUNT RATES, PORTFOLIO DIVERSIFICATION AND ACCESS TO CREDIT}

It has been theorized that poverty may lead to short planning horizons, which may in turn prevent rural households from investing in land use changes that yield benefits in the medium to long-term or conservation initiatives that will contribute to the sustainability of the natural resource base (Mink 1993; Pender 1996). This disincentive to invest in tree planting or conservation is related to the concept of discount rateswhich reflect how much the decision maker values having something today versus having it some time in the future. Higher discount rates indicate a desire to have returns now rather than in the future, and consequently a disincentive to invest in initiatives that are unlikely to provide returns in the short-term. ${ }^{30}$ Discount rates are particularly relevant to tree planting decisions. When a household's discount rate is high, the economic returns and environmental benefits associated with tree planting may take too long to accrue for the investment to be attractive. For this reason, fast growing species such as eucalyptus are more likely to be viable tree crops for smallholders.

Empirical estimates of discount rates for rural households in Ethiopia are few. Holden, Shiferaw, and Wik (1998) estimated the average discount rate in one of the most productive grain producing regions of Ethiopia to be $53 \%$, with the discount rate being inversely related to household wealth. ${ }^{31}$ Households with no oxen had an average discount rate of $79 \%$, whereas the average discount rate was estimated to be $28 \%$ for households with more than two oxen. If one hypothesizes that the poorest households likely reside on degraded land most in need of reclamation, or are in fact landless, the importance of choosing fast growing species for conservation and economic benefit is evident. It may be the case in some areas of the Ethiopian highlands that 5 or 10-year

${ }^{30}$ A discount rate reflects the marginal rate of inter-temporal substitution (Pender 1996). For example, with a discount rate of $50 \%$, benefits received in year one are valued at only two-thirds $(1 / 1.5)$ the value of an equivalent benefit that is received immediately after the investment is made. After 5 years, benefits are valued at only $13 \%$ of their original value.

${ }^{31}$ Pender (1996) also found this inverse relationship in India. 
tree rotations are too long to accommodate high household discount rates, implying that other conservation and income generation alternatives will need to be considered, unless increasing wealth, credit or other factors reduces poor household's discount rates.

Factors such as species type and altitude will affect the rate of growth of trees, and consequently have a significant impact on whether or not communities and smallholders will invest in tree planting. For example, poor smallholders with high discount rates living at high elevations (where trees grow slowly) may not find it attractive to invest in tree planting. Trees with very slow rates of growth (MAIs) mean that benefits are unlikely to be realized within a time horizon consistent with the smallholder's discount rate. This is particularly discouraging as the positive external benefits of afforestation and/or reforestation at high elevations are likely to lead to reductions in soil erosion and increase the availability of scarce biomass.

When discount rates are too high to make investments in tree planting profitable, access to rural credit may provide smallholders with the capital to make tree-planting investments. ${ }^{32}$ Because tree planting is characterized by high initial costs and returns in the medium to long run, the terms of borrowing should allow for repayment over a time period consistent with the harvest of the tree crop. Access to credit is likely to be most important to women, the poor and other marginalized groups that have few assets and find it difficult to invest in land uses with medium term benefits.

When credit is not constrained, people will theoretically discount at the market rate of interest (Pender 1996). The presence of such high discount rates and informal sector interest rates in Ethiopia (for example, Holden, Shiferaw, and Wik 1998; and Table 11 below) reflects credit constraints and suggests that expanded credit availability could reduce discount rates and make tree planting and other investments more attractive.

${ }^{32}$ Access to credit (not necessarily subsidized) can reduce households' discount rates by increasing their ability to satisfy current needs without sacrificing investments in the future (Pender 1996). 
Table 11 Credit market characteristics, Tigray $1998^{a}$

\begin{tabular}{lccc}
\hline Source of credit & $\begin{array}{c}\text { Average annual } \\
\text { interest rate }\end{array}$ & $\begin{array}{c}\text { Proportion of } \\
\text { households using } \\
\text { type of credit }\end{array}$ & $\begin{array}{c}\text { Average repayment } \\
\text { terms (months) }\end{array}$ \\
\hline $\begin{array}{l}\text { Relief Society of } \\
\text { Tigray/Dedebit }\end{array}$ & 12.33 & $44 \%$ & 11.64 \\
Bureau of Agriculture & $(0.10)$ & $23 \%$ & $(0.20)$ \\
& 11.20 & & 10.99 \\
Money Lender & $(0.66)$ & $5 \%$ & $(3.20)$ \\
& 34.49 & & 4.82 \\
& $(6.56)$ & $1.62)$ \\
\hline
\end{tabular}

${ }^{\mathrm{a}}$ Values in parentheses are standard errors. All means and standard errors are corrected for sampling stratification and sampling weights.

Credit from formal credit sources such as the Relief Society of Tigray is available at a much lower annual interest rate than credit from informal sources such as moneylenders. Formal credit is very limited in availability however, so most poor smallholders likely face binding credit constraints (Hagos, Pender, and Gebreselassie 1999). The period of repayment for informal credit is shorter than for formal credit. However, all credit is relatively short term, limiting the ability to use credit to finance longer-term investments such as tree planting.

If discount rates are low enough for tree planting to be profitable and credit is available, then portfolio diversification that incorporates trees into land use systems is a consideration. Generally it is not clear whether diversification from a single crop to a system including multiple outputs is economically optimal. Economic analyses of agroforestry systems based on considerations of profit alone suggest that the production of only one crop is optimum (Filius 1982). This finding is based on the standard theory of comparative advantage - if risks are not considered the economic decision making unit should produce the good it has relative efficiency in producing. However, when risk is incorporated into the analysis, diversified land use portfolios may be optimal. If risk in one crop is not highly correlated with risk in another crop, the optimal solution may be a multiple crop system to diversify risk (Blandon 1985). If one crop is suffers stress or 
destruction due to factors such as pests, extreme weather, etc., the other crop or crops may survive, providing a source of food and/or income. Planting trees on a plot of land may be influenced by the need to insure against risk as well as desire to attain the highest economic return (Livingstone 1986). Portfolio diversification by planting trees may thus help farmers to become more food secure in regions characterized by fragile lands, extreme climatic variation and high rates of poverty such as the Ethiopian highlands, which are at high risk for crop failure, livestock mortality or both.

\section{INSTITUTIONS}

Intensity of management may have a significant impact on the economic returns realized from tree planting. Intensive management refers to management activities such as building individual fences around seedlings in the first few years of production, and watering trees as needed. More intensively-managed woodlots should yield higher survival rates resulting in higher economic returns, but also higher costs. We hypothesize that community and private woodlots will be managed with different levels of intensity, and that for Tigray, households that privately manage woodlots on communal land will manage more intensively than community groups and achieve higher expected survival rates. Private woodlots are more likely to be intensively managed because households generally receive the full benefit of their own effort, whereas the guarantee of reaping the benefits of planting trees in community woodlots is less clear. Greater assurance of benefits implies greater incentive to invest in private woodlots, yielding higher survival rates. We also expect that kushet community woodlots will be more intensively managed than tabia community woodlots as incentives are more diluted at the tabia level and collective action more difficult to attain, suggesting higher survival rates for kushet than tabia community woodlots. Table 12 summarizes stand survival rates (as a percentage of the total number of seedlings planted for the most commonly observed tree species in the region.

Survival rates for eucalyptus are generally higher for privately managed woodlots than for community-managed woodlots. However, this is not observed for all species and in some cases survival rates are higher for community woodlots than for private 
woodlots. The fact that we don't find higher survival rates for kushet managed community woodlots suggests that kushets may be pursuing an approach of planting trees more densely and then thinning them (data in Table 6 for estimated planting densities supports this hypothesis). ${ }^{33}$ Given the low cost of seedlings, this may be a very efficient approach to tree planting.

Table 12 Survival rates for stands of trees in community and private woodlots, percent $^{\mathrm{a}}$

\begin{tabular}{lcccc}
\hline Tree species & \multicolumn{2}{c}{ Tabia } & \multicolumn{2}{c}{ Kushet } \\
\cline { 2 - 5 } & $\begin{array}{c}\text { Community } \\
\text { woodlots } \\
(\mathrm{n}=108)\end{array}$ & $\begin{array}{c}\text { Private } \\
\text { woodlots } \\
(\mathrm{n}=36)\end{array}$ & $\begin{array}{c}\text { Community woodlots } \\
(\mathrm{n}=518)\end{array}$ & $\begin{array}{c}\text { Private } \\
\text { woodlots } \\
(\mathrm{n}=49)\end{array}$ \\
\hline E. camaldulensis & 51 & 65 & 50 & 58 \\
& $(9.90)$ & $(16.83)$ & $(4.48)$ & $(4.56)$ \\
E. globulus & 42 & 87 & 64 & 79 \\
& $(20.17)$ & $(5.52)$ & $(5.99)$ & $(6.57)$ \\
Leucaena leucocephala & 78 & 85 & 54 & 54 \\
& $(3.42)$ & $(12.89)$ & $(8.56)$ & 53 \\
Acacia saligna & 81 & $\mathrm{~N} / \mathrm{A}$ & 60 & $(1.01)$ \\
& $(3.31)$ & & $(7.65)$ & 44 \\
Olea africana & 59 & 37 & 38 & $(4.84)$ \\
& $(9.64)$ & $(12.33)$ & $(6.55)$ & N/A \\
Dodnia augustifolia & 93 & $\mathrm{~N} / \mathrm{A}$ & 56 & $(8.56)$ \\
& $(3.56)$ & & 51 & 52 \\
All observed species & 69 & 67 & $(3.43)$ & $(5.08)$ \\
\hline
\end{tabular}

\footnotetext{
${ }^{\mathrm{a}}$ Values in parentheses are standard errors. All means and standard errors are corrected
} for sampling stratification and sampling weights.

${ }^{33}$ Although survival rates are generally highly correlated with the age of trees, survival rate data for all species of trees planted in Tigray indicate that age of tree and survival rates were not correlated. The lowest survival rates were observed in the period 1992-1995 across all management categories, with higher survival rates observed both before and after this period. 
Right of access and use to the products that are produced from woodlots is an institutional factor that may influence long-term investments such as tree planting. In Tigray, smallholders generally require permission from the Bureau of Agriculture and Natural Resource Development to harvest products such as poles and firewood. If smallholders perceive that they may not be given approval to harvest products from woodlots that they have invested in, they are less likely to get involved in community tree planting due to the uncertainty of when or if they will benefit from their investment. Smallholders that plant trees on privately managed plots of community land may be less likely to face such constraints. As noted earlier, few people have been allowed to cut trees from community woodlots in Tigray, reducing the benefit of investing scarce resources in tree planting. ${ }^{34}$

The final institutional consideration we present is the value of effective collective action for maximizing the benefits of land use investments. When trees are planted collectively the greatest number of people benefit, ensuring more equal access for all, but particularly for poor households. ${ }^{35}$ It is implicitly assumed that through cooperative ventures the flow of benefits from trees can be conserved and equally distributed among smallholders who represent the majority in rural communities (Arnold 1984; Cernea 1981; Runge 1992). However, the problems associated with open access and "free riding" often presents a barrier to the success of collective tree planting investments. When all community members have access to a common pool resource, regardless of the investment that they made in managing the resource, there is a disincentive to act collectively. Rational individuals will free ride under circumstances where the group is large or there is the potential for the individual to be excluded from the group (Wade

${ }^{34}$ Uncertainty of benefits, or having to wait to long to harvest trees and other woodlot benefits is also related to the issue of discount rates. Households with high discount rates will need to acquire benefits sooner, suggesting that to successfully promote community tree planting, local governments need to allow people to harvest woodlot products sooner.

35 The rural poor typically have less land and rely significantly more on common property resources to provide household subsistence needs (Jodha 1986). 
1992). Particularly where monitoring and enforcement mechanisms are weak the incentive to free ride is pervasive. In many cases, under the Derg, trees that were planted on state or community plots had poorly defined tree tenure rights resulting in little incentive for groups to plant and maintain trees (Bruce, Hoben, and Rahmato 1994).

The reasons to plant and manage trees privately include assurance of acquisition of perceived net benefits, relative security involved in the investment, and the opportunity cost of undertaking the land use change within the context of the farm production system (Gregersen, Draper, and Elz 1989). Private tree planting investments may be characterized by direct correlation between inputs, such as labor and materials, and outputs, providing the decision-maker with a direct, easily understood, proportionate and less uncertain correlation between investment and returns (Gregersen, Draper, and Elz 1989). Distribution of benefits is generally simplified under private ownership or management, but private individuals may also be subject to regulatory authority with regard to management techniques, and timing and quantity of harvest, particularly when planting on community lands.

In Tigray, collective action on community woodlots appears to work relatively well (Gebremedhin, Pender, and Tesfaye 1999). Based upon community-level data comparing kushet and tabia managed woodlots, they find that collective action may be more effective when managed at a more local level (i.e., at the village level rather than the tabia level), when complementary inputs are provided by external organizations, and when promoted in medium population density regions that are more remote from markets. Conversely, they argue that private woodlots are likely to function more effectively in densely populated communities with comparatively good access to markets.

\section{DISCUSSION—ECONOMIC INCENTIVES FOR TREE PLANTING}

In the preceding section we have discussed several of the economic conditions that may influence communities and private smallholders in the Ethiopian highlands to make tree-planting investments. Based upon the economic relationships that shape land use decisions in the Ethiopian highlands region, we hypothesize that there are certain 
conditions under which the planting of eucalyptus may yield appropriate economic returns and environmental benefits. To summarize, tree planting is likely to be most profitable:

- in areas with low to moderate population densities,

- on land having low agricultural potential, except perhaps in high altitude areas where tree growth is slow,

- in regions with good market access,

- in regions with tree product markets that have sufficiently elastic demand,

- where farmers have access to credit or sufficient wealth to finance long term investments,

- where individuals are allowed secure access to benefits of their investments.

Regions that are not resource constrained by high population densities are likely

to have land suitable for tree planting investments. However, geographical variables such as altitude that may significantly affect rates of tree growth will also affect whether or not tree-planting investments are profitable for smallholders. Further, issues of market access, including access to both input and output markets, as well as access to off-farm employment opportunities are likely to additionally influence incentives to invest in tree planting. Estimates of costs and returns are needed to recognize how important the factors we have listed above are with respect to identifying opportunities for farm investments and possible policy actions to facilitate socially beneficial tree planting investments.

\section{ESTIMATED ECONOMIC RETURNS}

In this section we estimate internal rates of return (IRR) for community and privately managed woodlots. IRR represents the breakeven discount rate, the rate at which the present value of benefits equals the present value of costs. IRR is formally expressed as:

$$
\sum_{t=0}^{T} \frac{R_{t}}{(1+r)^{t}}=\sum_{t=0}^{T} \frac{C_{t}}{(1+r)^{t}} ;
$$


where $R_{t}, C_{t}$, are revenue and cost at time $t$, and $\mathrm{T}$ is the time horizon of the investment (Price 1989). Internal rates of return represent what households can expect to receive in consumption benefits for a given investment of their scarce resources (FAO 1992).

In addition to base case estimates we consider the influence of variable harvesting periods, the value of crop losses related to potential negative externalities, and the influence that factors such as variable wages and prices have on rates of return. Due to limited data, benefit-cost estimates are based on simple parameters and sensitivity analysis is designed to reflect the key variables we hypothesize influence returns to investment for tree planting.

\section{BASE CASE}

To determine which variables influence returns to tree planting we first estimate internal rates of return for a base case. Estimates are based upon the summary statistics presented for tabia and kushet community woodlots and privately managed stands of eucalyptus that were presented in the previous section. Unless otherwise specified the same assumptions and sensitivity analysis parameters apply to estimates for both community and privately managed woodlots. The assumptions we make regarding the various parameters and criteria for sensitivity analysis of the value of land, labor, seedlings, poles and grass for rate of return estimates are summarized in Table 13.

The woodlot benefits that we value in our analysis are poles and grass. Pole production is adjusted for woodlot survival rates, and we assume based upon survey data that grass production will occur only the first three years of woodlot production. Trees should be established by that time and grass growth limited. For land with zero opportunity cost (for example, wasteland) we assume zero grass production. Other eucalyptus benefits that have been excluded from our analysis include fuelwood and honey, as well as the value of any benefits that might arise as positive externalities such as soil erosion control. We also omit input costs other than labor and seedlings (for example, fencing material costs), the value of water used in woodlots, and potential negative externalities such as excessive water use by trees. 
We assume that the first harvest of the total tree crop will take place in year 10 of production, with subsequent harvests of coppice crops taking place in years 20 and 30. These assumptions are based upon data presented in Poshen-Eiche (1987), and reflect harvesting patterns observed in the Hararghe Highland region of Ethiopia. Although it is likely smallholders will harvest some proportion of their crop as early as year 5 or 6 of production (if allowed by the Administration governing the woodlot), in the absence of data to validate this hypothesis we follow the above conservative assumptions regarding harvesting patterns and returns.

Internal rate of return (IRR) estimates for the base case scenario are summarized in Table 14. If we assume that any IRR above 10-12\% represents efficient land use then we can conclude from the above estimates that community and privately managed stands of eucalyptus tree are generally highly profitable in Tigray for the given set of data and assumptions that we have presented. However, it is likely, based upon observations of local informal interest rates and estimated discount rates for smallholders in Tigray, that these rates of return may not be high enough to make tree-planting investments attractive to many households (see Table 11).

IRR estimates for kushet-managed community woodlots and privately managed woodlots are higher than those for tabia-managed community woodlots. These differences are largely attributable to lower survival rates and the lesser amount of grass collected in tabia woodlots. This finding suggests that more localized or private management of woodlots yields higher returns on investment. Given that our estimates are based on an assumption of three separate harvests of the total standing tree stock, it is interesting to consider how rates of return might change if access to benefits (i.e. poles) were limited by woodlot governing bodies as is often the case with community woodlots. If pole production is reduced to half of the total stock in each consecutive 
Table 13 Summary of parameter assumptions and sensitivity analysis values, base case

\begin{tabular}{|c|c|c|c|c|}
\hline Cost or benefit & Parameter & Assumptions & Values & Data source \\
\hline Cost, land & $\begin{array}{l}\text { Value per hectare } \\
\text { of land }\end{array}$ & $\begin{array}{l}\text { Analysis is at the hectare level, the } \\
\text { value of land is based upon estimated } \\
\text { opportunity cost (gross per hectare } \\
\text { value of farmland) }\end{array}$ & $\begin{array}{l}\text { Land value }=0 \text { birr/hectare } \\
\text { (wasteland) } \\
\text { Land Value }_{2}=841 \text { birr/hectare }\end{array}$ & See summary Tables 5 \\
\hline Cost, labor & Value of labor & $\begin{array}{l}\text { Wage rates are estimated from survey } \\
\text { data } \\
\text { Based upon survey estimates of labor } \\
\text { inputs by age of woodlot }\end{array}$ & $\begin{array}{l}\text { Wage Rate }_{1}=4 \text { Wage Rate } \\
\text { birr/day birr/day }\end{array}$ & $\begin{array}{l}\text { See summary Tables } 7 \\
\text { and } 8\end{array}$ \\
\hline Cost, seedlings & Value of seedlings & $\begin{array}{l}\text { All seedlings are valued at } 1 \text { cent birr } \\
\text { per seedling } \\
\text { Utilized median planting densities for } \\
\text { eucalyptus species }\end{array}$ & $\begin{array}{l}\text { Seedling= } 1 \text { cent birr/seedling } \\
\text { tabia woodlots } 3287 \text { trees per } \\
\text { hectare } \\
\text { kushet woodlots } 4717 \text { trees per } \\
\text { hectare } \\
\text { private woodlots } 3024 \text { trees } \\
\text { per hectare }\end{array}$ & $\begin{array}{l}\text { Personal } \\
\text { communication } 2000 . \\
\text { Berhanu Gebremedhin } \\
\text { See summary Table } 6\end{array}$ \\
\hline Benefit, poles & $\begin{array}{l}\text { Value poles } \\
\text { harvested }\end{array}$ & $\begin{array}{l}\text { Estimates of mean pole prices in each } \\
\text { tabia and woreda town are used } \\
\text { Poles produced are adjusted for survival } \\
\text { rates for eucalyptus species }\end{array}$ & $\begin{array}{l}\text { Pole Price }_{1}=17 \text { birr } / \text { pole } \\
\text { Pole Price }=30 \text { birr/pole } \\
\text { Pole Price } 3=41 \text { birr/pole } \\
\text { tabia woodlots } 47 \% \text { survival } \\
\text { rate }\end{array}$ & $\begin{array}{l}\text { See summary Tables } 9 \\
\text { and } 12\end{array}$ \\
\hline
\end{tabular}




\begin{tabular}{|c|c|c|c|c|}
\hline Cost or benefit & Parameter & Assumptions & Values & Data source \\
\hline \multirow{3}{*}{ Benefit, grass } & \multirow{3}{*}{$\begin{array}{l}\text { Value grass } \\
\text { harvested }\end{array}$} & & $\begin{array}{l}\text { kushet woodlots } 58 \% \text { survival } \\
\text { rate } \\
\text { private woodlots } 71 \% \\
\text { survival rate }\end{array}$ & \multirow{3}{*}{ See summary Table 10} \\
\hline & & Estimates of mean grass production & $\begin{array}{l}\text { Grass Price }_{1}=6.5 \\
\text { birr/head load }\end{array}$ & \\
\hline & & $\begin{array}{l}\text { Grass production for only the first three } \\
\text { years of woodlot production on land } \\
\text { with a positive opportunity cost. }\end{array}$ & $\begin{array}{l}\text { tabia woodlots } 22 \text { head loads } \\
\text { per hectare } \\
\text { kushet and privately managed } \\
\text { woodlots } 161 \text { head loads per }_{\text {hectare }^{\mathrm{a}}}\end{array}$ & \\
\hline Rotation Age & $\begin{array}{l}\text { Age of } 1^{\text {st }}, 2^{\text {nd }}, \\
\text { and } 3^{\text {rd }} \text { harvest }\end{array}$ & $\begin{array}{l}\text { We assume the total standing stock of } \\
\text { trees is harvested in each period }\end{array}$ & $\begin{array}{l}1^{\text {st }} \text { Harvest }=\text { Yr } 10 \\
2^{\text {nd }} \text { Harvest }=\text { Yr } 20 \\
3^{\text {rd }} \text { Harvest }=\text { Yr } 30\end{array}$ & Poschen-Eiche 1987 \\
\hline
\end{tabular}

${ }^{\mathrm{a}}$ We rely on kushet-managed community woodlots to provide estimates of labor inputs for privately managed woodlots in the first three years that the woodlot is established, as well as an estimate of the amount of grass production that a one-hectare private woodlot might produce in each of the first three years of tree production. Given data on average labor inputs, mean densities and survival rates, we assume that community level kushet woodlots are managed relatively more intensively than tabia community woodlots.

${ }^{\mathrm{b}}$ We employ median planting density values in our analysis as outliers in the data were causing very high estimates of mean planting density, particularly for tabia-managed woodlots and privately managed woodlots (see Table 6). 
Table 14 Internal rate of return estimates for base case scenario

\begin{tabular}{|c|c|c|c|c|c|c|}
\hline & \multicolumn{2}{|c|}{$\begin{array}{l}\text { Community- } \\
\text { managed tabia } \\
\text { woodlots }\end{array}$} & \multicolumn{2}{|c|}{$\begin{array}{l}\text { Community- } \\
\text { managed kushet } \\
\text { woodlots }\end{array}$} & \multicolumn{2}{|c|}{$\begin{array}{l}\text { Privately-managed } \\
\text { woodlots on } \\
\text { community land }\end{array}$} \\
\hline & $\begin{array}{c}\text { No grass } \\
\text { harvest }\end{array}$ & $\begin{array}{c}\text { Grass } \\
\text { harvest }\end{array}$ & $\begin{array}{c}\text { No grass } \\
\text { harvest }\end{array}$ & $\begin{array}{c}\text { Grass } \\
\text { harvest }\end{array}$ & $\begin{array}{c}\text { No grass } \\
\text { harvest }\end{array}$ & $\begin{array}{c}\text { Grass } \\
\text { harvest }\end{array}$ \\
\hline \multicolumn{7}{|l|}{ Land value $=0$} \\
\hline \multicolumn{7}{|l|}{ Wage rate $=4$} \\
\hline Pole price $=17$ & $41 \%$ & $\mathrm{~N} / \mathrm{A}$ & $55 \%$ & $\mathrm{~N} / \mathrm{A}$ & $51 \%$ & N/A \\
\hline Pole price $=30$ & $50 \%$ & N/A & $65 \%$ & $\mathrm{~N} / \mathrm{A}$ & $61 \%$ & $\mathrm{~N} / \mathrm{A}$ \\
\hline Pole price $=41$ & $55 \%$ & $\mathrm{~N} / \mathrm{A}$ & $72 \%$ & $\mathrm{~N} / \mathrm{A}$ & $67 \%$ & $\mathrm{~N} / \mathrm{A}$ \\
\hline \multicolumn{7}{|l|}{ Wage rate $=8$} \\
\hline Pole price $=17$ & $32 \%$ & N/A & $44 \%$ & N/A & $40 \%$ & $\mathrm{~N} / \mathrm{A}$ \\
\hline Pole price $=30$ & $39 \%$ & $\mathrm{~N} / \mathrm{A}$ & $53 \%$ & $\mathrm{~N} / \mathrm{A}$ & $49 \%$ & $\mathrm{~N} / \mathrm{A}$ \\
\hline Pole price $=41$ & $44 \%$ & $\mathrm{~N} / \mathrm{A}$ & $59 \%$ & N/A & $54 \%$ & $\mathrm{~N} / \mathrm{A}$ \\
\hline \multicolumn{7}{|l|}{ Land Value $=841$} \\
\hline \multicolumn{7}{|l|}{ Wage rate $=4$} \\
\hline Pole price $=17$ & $22 \%$ & $23 \%$ & $31 \%$ & $50 \%$ & $27 \%$ & $44 \%$ \\
\hline Pole price $=30$ & $31 \%$ & $32 \%$ & $41 \%$ & $64 \%$ & $37 \%$ & $58 \%$ \\
\hline Pole price $=41$ & $36 \%$ & $37 \%$ & $47 \%$ & $72 \%$ & $43 \%$ & $66 \%$ \\
\hline \multicolumn{7}{|l|}{ Wage rate $=8$} \\
\hline Pole price $=17$ & $19 \%$ & $20 \%$ & $28 \%$ & $39 \%$ & $25 \%$ & $34 \%$ \\
\hline Pole price $=30$ & $27 \%$ & $28 \%$ & $38 \%$ & $51 \%$ & $33 \%$ & $45 \%$ \\
\hline Pole price $=41$ & $32 \%$ & $33 \%$ & $43 \%$ & $57 \%$ & $39 \%$ & $52 \%$ \\
\hline
\end{tabular}

harvest period, IRR estimates drop from $64 \%$ to $47 \%$ for kushet woodlots. ${ }^{36}$ For very poor households with high discount rates, lack of assurance of full benefits in return for investing in woodlots may be enough to deter investment.

Finally we note that land values have a greater effect on rate of return estimates than pole prices and wage rates, implying that the opportunity cost of land is an important consideration when planting eucalyptus trees. This has implications when considering the issue of planting trees on farmlands vs. wastelands. We note however that the upper limit of opportunity cost is an over estimate, even for farmlands, since they are based on

${ }^{36}$ These estimates are based upon the following criteria, low wage rates (4 birr/day), mid-range pole prices (30 birr/pole), positive opportunity cost of land (841 birr/ha), and grass collection allowed in the first three years of woodlot production. 
gross, rather than net, returns to cropland. They are even more of an overestimate for less productive lands.

\section{IMPACT OF DIFFERENT HARVEST PERIODS}

The base case analysis assumed rates of tree growth that allow for the harvest of the total tree stock in year 10 of production followed by subsequent harvests of coppice crops in production years 20 and 30. These harvest ages are assumed to represent an average case for the Ethiopian highlands region. We hypothesize however factors such as altitude and land potential will have a significant impact on rates of tree growth (MAI/ha). Based upon anecdotal evidence from Tigray we assume that communities and smallholders that plant eucalyptus trees at lower elevations or on high potential lands may be able to harvest stocks as early as year 5 in the production cycle, with subsequent harvests at years 10 and 15. Conversely, tree-planting investments made at very high elevations and/or on low potential lands may not allow for the first harvest until as late as year 15 of production, with subsequent harvests of coppice crops taking place in years 30 and 45. Table 15 summarizes rate of return estimates for short, average and long rotation cycles, with varying land values, wages pole prices and other factors for tabia community woodlots as explained in Table 13. 
Table 15 Effect of different harvesting periods on rate of return estimates

\begin{tabular}{|c|c|c|c|}
\hline & \multicolumn{3}{|c|}{ Tabia-managed community woodlots } \\
\hline & $\begin{array}{l}\text { 5-year harvest } \\
\text { rotation }\end{array}$ & $\begin{array}{l}\text { 10-year harvest } \\
\text { rotation }\end{array}$ & $\begin{array}{l}\text { 15-year harvest } \\
\text { rotation }\end{array}$ \\
\hline \multicolumn{4}{|l|}{ Land value $=0$} \\
\hline \multicolumn{4}{|l|}{ Wage rate $=4$} \\
\hline Pole price $=17$ & $119 \%$ & $41 \%$ & $25 \%$ \\
\hline Pole price $=30$ & $152 \%$ & $50 \%$ & $29 \%$ \\
\hline Pole price $=41$ & $173 \%$ & $55 \%$ & $32 \%$ \\
\hline \multicolumn{4}{|l|}{ Wage rate $=8$} \\
\hline Pole price $=17$ & $86 \%$ & $32 \%$ & $19 \%$ \\
\hline Pole price $=30$ & $113 \%$ & $39 \%$ & $24 \%$ \\
\hline Pole price $=41$ & $130 \%$ & $44 \%$ & $26 \%$ \\
\hline \multicolumn{4}{|l|}{ Land value $=841$} \\
\hline \multicolumn{4}{|l|}{ Wage rate $=4$} \\
\hline Pole price $=17$ & $75 \%$ & $22 \%$ & $11 \%$ \\
\hline Pole price $=30$ & $104 \%$ & $31 \%$ & $16 \%$ \\
\hline Pole price $=41$ & $122 \%$ & $36 \%$ & $19 \%$ \\
\hline \multicolumn{4}{|l|}{ Wage rate $=8$} \\
\hline Pole price $=17$ & $62 \%$ & $19 \%$ & $10 \%$ \\
\hline Pole price $=30$ & $86 \%$ & $27 \%$ & $15 \%$ \\
\hline Pole price $=41$ & $102 \%$ & $32 \%$ & $17 \%$ \\
\hline
\end{tabular}

The results in Table 15 illustrate the strong influence of growth rates on returns to investment for tree planting. Tabia-managed woodlots are clearly highly profitable when the first harvest of tree stocks can be undertaken in year 5 of production, and every five years to year 15. However, rate of return estimates for woodlots that are harvested less frequently (for example, woodlots planted on high altitude sites) indicate that tree planting investments may not offer sufficient returns, especially for poor households, particularly when the value of cropland is high. Tabia-managed woodlots are profitable on varying land quality sites if we take $10 \%$ as an acceptable rate of return. If we consider $50 \%$ as an acceptable rate of return for tree planting investments then mainly stands of eucalyptus planted on lower altitude sites with high mean annual increments will be profitable. 
The issue of harvesting period or rotation age raises an interesting question - the long-term sustainability of investments in eucalyptus. If we consider the shorter rotation age of 5 years and assume three productive harvest periods, eucalyptus woodlots may have surpassed the peak of their productive life after only 15 or 20 years of production. The question of what to do with the site after the productive life of the woodlot has ended will have implications for smallholders that have planted trees on farmlands or other areas with positive opportunity costs. ${ }^{37}$ For example, if a smallholder produced eucalyptus trees on farmland for 20 years and at the end of that period decided to return that land to cropland, the labor and other costs involved in removing stumps and the opportunity cost of a fallow period for the site may be high. The long-term ecological consequences are ambiguous. Soil and water resources may be depleted from 20 years of intensive tree growing, but the positive effect of 20 years of tree cover and organic matter produced from decomposing tree roots may outweigh nutrient and water depletions. This question should be considered carefully when considering new forest policy for northern Ethiopia.

\section{IMPACT OF CROP LOSSES DUE TO NUTRIENT AND WATER UPTAKE BY EUCALYPTUS}

As we have already noted, eucalyptus trees may reduce crop yields on plots adjacent to woodlots or rows of trees. The allelopathic effects of eucalyptus and competition for water and soil nutrients when planted adjacent to food crops, or intercropped with cereals or vegetables may lead to losses in food crop production that may affect household food security and income. Although a complete portfolio analysis of the various land use activities smallholders undertake is necessary to fully understand the effect of tree related crop losses on smallholder livelihoods, we incorporate crop losses to neighbors into the tree production rate of return estimates to provide a rough estimate of the impact of potential losses from a social rate of return perspective.

${ }^{37} \mathrm{We}$ assume that the long-term benefit of planting trees on wasteland will be positive regardless of whether or not the site is cleared of stumps and replanted or allowed to lie fallow after years of eucalyptus production. 
We consider a situation where a smallholder plants eucalyptus trees on a onehectare square plot. Four neighboring smallholders surround the woodlot, each farming cereal crops on a one-hectare plot on each side of her plot. If we assume that $100 \%$ of crop yield will be lost within 10 meters of the trees, each of the four neighboring smallholders will loose $11 \%$ of their gross crop production. The total loss to all four smallholders is equivalent to 370 Ethiopian birr (assuming a land value of $841 \mathrm{birr} / \mathrm{ha}$ ). We estimate a social rate of return for private eucalyptus woodlots adapting our base case scenario by adding 370 birr to our opportunity cost of land estimates for woodlots planted on sites with an initially positive opportunity cost. Results are presented in Table 16.

\section{Table 16 Effect of crop losses on rate of return estimates}

\begin{tabular}{ccc}
\hline & Privately-managed woodlots on community land \\
\hline & $\begin{array}{c}\text { Base case } \\
\text { (private rate of return) }\end{array}$ & $\begin{array}{c}\text { Social rate of return } \\
\text { accounting for crop losses }\end{array}$ \\
Land value $=841$ & & \\
Wage rate $=4$ & $27 \%$ & $23 \%$ \\
Pole price $=17$ & $37 \%$ & $32 \%$ \\
Pole price $=30$ & $43 \%$ & $37 \%$ \\
Pole price $=41$ & & \\
Wage rate $=8$ & & $21 \%$ \\
Pole price $=17$ & $25 \%$ & $29 \%$ \\
Pole price $=30$ & $33 \%$ & $35 \%$ \\
Pole price $=41$ & $39 \%$ & \\
\hline
\end{tabular}

When compared with base case estimates the impact of crop losses does not alter the rate of return estimates substantially. These rates of return estimates indicate that social cost of planting eucalyptus trees is relatively small and that the benefits associated with growing trees may compensate for any losses in crop production. As we have discussed in previous sections of this paper, the issue of tradeoffs is very important to the question of whether or not eucalyptus should be legally planted on farmlands in Tigray. This scenario presents evidence suggesting that the value of trees may be sufficient to 
offset losses in crop production attributable to eucalyptus. However we note that the above estimates do not take into account possible off-site (i.e., downstream) effects etc.

\section{DIFFERENCES IN RATES OF RETURN ACROSS ZONES IN TIGRAY}

To illustrate the types of sites that may be most appropriate for eucalyptus tree planting we consider variables including opportunity cost of land, wages and prices at the zone level and their effect on rate of return estimates. Although zones in Tigray are defined by administrative boundaries that do not inherently reflect land quality etc., we can draw some inferences about the potential for planting eucalyptus in each zone from the data in earlier sections. Rates of return based upon average estimated opportunity cost of land, wages and pole prices are estimated for kushet community woodlots by zone and compared with a base case example in Table 17. Rate of return estimates illustrate

\section{Table 17 IRR estimates for kushet community woodlots by zone}

\begin{tabular}{ll}
\hline Zone & IRR \\
\hline Southern & $37 \%$ \\
Central & $45 \%$ \\
Eastern & $38 \%$ \\
Western & $28 \%$ \\
Base Case $^{\text {a }}$ & $41 \%$ \\
\hline
\end{tabular}

${ }^{\mathrm{a}}$ The base case we use for comparison purposes in Table 17 is the case where opportunity cost of land is positive ( $841 \mathrm{birr} / \mathrm{ha})$, wage rates $4 \mathrm{birr} /$ day, pole prices are 30 birr/pole and no grass is harvested from the woodlot.

the how rates of return may vary between regions. Predicted rates of return are slightly below the base case in the Southern and Eastern zones, and well below the base case in the Western zone. High opportunity cost of land, low pole prices and average wage rates are characteristics of the Western Zone. The Central Zone has the highest predicted rate of return for kushet community woodlots due to its relatively low opportunity cost of land and high pole prices. Results indicate that regions such as the Central Zone, with low 
opportunity cost of land and market conditions that support high output prices favor woodlot production.

\section{POLICY OPTIONS FOR NORTHERN ETHIOPIA}

As we have seen, eucalyptus trees offer potentially high net returns to investment in many parts of northern Ethiopia, in many cases even when they completely displace crop production. This is due to the low productivity and profitability of crop production in low potential areas in northern Ethiopia, the scarcity and high value of timber and nontimber tree products in this region, and the ability of eucalyptus trees to produce valuable biomass quickly.

The current policy in Tigray bans planting eucalyptus trees in farmlands but seeks to promote planting of eucalyptus and other trees in community woodlots. However, the regional Bureau of Agriculture regulates the use of trees in community woodlots, and few communities have been allowed to cut trees from their woodlots, potentially undermining their interest in investing in community woodlots. The regional Bureau of Agriculture is pilot-testing an approach allowing hillsides and degraded land to be allocated by communities for private tree planting or other permitted uses, and the Regional Council has asked the Bureau to develop a policy on this. Many communities appear to be pursuing this approach on their own initiative, however.

Several policy options could be considered to take advantage of the potential offered by eucalyptus and other trees in northern Ethiopia. The policies we discuss in this section are related to improving the management of community woodlots and/or actively promoting private tree planting and management. ${ }^{38}$ The potential impacts of such policy options, relative to current policy, should be considered before any policy changes are made. Several criteria will likely be important to policy makers in northern Ethiopia, including impacts on the wealth and income of people in rural areas, impact on

${ }^{38}$ Most of these options are not mutually exclusive. The regional government could choose to pursue more than one of these options. 
food security, ecological impacts of the options and their implications for the sustainability of incomes and resources, and ease and cost of implementing whatever policy option is considered. The policies and their predicted impact relative to current policy are summarized in Table 18 - each option is then discussed in turn. This exercise is meant to be suggestive rather than definitive, suggesting an approach to policy analysis of this issue that may be useful to policy analysts in Ethiopia.

\section{PROMOTING MORE LOCALIZED WOODLOT MANAGEMENT}

At present, communities must obtain permission from the woreda Bureau of Agriculture before harvesting poles and/or fuelwood from their woodlots. Data from our community survey indicates that harvesting had been allowed in only 10 out of more than 1,800 stands of trees, even though nearly one-fifth of these stands were established before 1991. ${ }^{39}$ As a result, the timber benefits to local communities from the woodlots have thus far been small. The main benefits received to date have been from cutting grass for fodder. However, only $31 \%$ of kushet-managed woodlots received benefits from grass cutting in 1998, and the average value of benefit was only about 2 EB per capita for the villages where benefits were received (Berhanu, Pender, and Girmay 1999). Grass cutting benefits from tabia-managed woodlots were even lower, averaging only $0.10 \mathrm{~EB}$ per capita. These benefits were comparable to the average value of labor input provided in 1998 by village members to manage kushet woodlots, but were substantially lower than the labor input provided for tabia-managed woodlots (Ibid.).

Given that access to benefits is currently limited, more localized management of community woodlots could be considered to increase near-term economic benefits. Allowing kushets and tabias to decide on their own when to harvest timber and non-

${ }^{39}$ Recall that a "stand" is a group of trees of a particular species within a woodlot planted in a particular year. 
Table 18 Summary of policy options and possible impacts, relative to current policy in Tigray

\begin{tabular}{|c|c|c|c|c|c|}
\hline Policy option & $\begin{array}{l}\text { Aggregate income } \\
\text { and wealth }\end{array}$ & Food security & $\begin{array}{l}\text { Distribution of benefits } \\
\text { and costs }\end{array}$ & $\begin{array}{l}\text { Ecological } \\
\text { impacts }\end{array}$ & $\begin{array}{l}\text { Ease and cost of } \\
\text { implementation }\end{array}$ \\
\hline $\begin{array}{l}\text { 1. Promoting more localized } \\
\text { management of community } \\
\text { woodlots by: } \\
\text {-Increasing local authority } \\
\text { to manage woodlots } \\
\text {-Encouraging management } \\
\text { of woodlots at kushet level }\end{array}$ & Positive impact $(+)$ & + & $\begin{array}{l}\text { Uncertain impact, } \\
\text { probably minor }(? / 0)\end{array}$ & $\begin{array}{l}\text { Possible positive } \\
\text { or negative } \\
\text { impacts }(+/-)\end{array}$ & $\begin{array}{l}\text { Easier to administer, though } \\
\text { some monitoring and training } \\
\text { still needed. Kushet level } \\
\text { management easy to implement } \\
\text { if left up to local communities } \\
(+)\end{array}$ \\
\hline $\begin{array}{l}\text { 2. Allocate part or all of } \\
\text { community woodlots for private } \\
\text { management }\end{array}$ & $\begin{array}{l}\text { Positive impact, } \\
\text { possibly larger than } \\
\text { option } 1\end{array}$ & + & $\begin{array}{l}\text { Depends on how } \\
\text { implemented (?) }\end{array}$ & $\begin{array}{l}\text { Possible mixed } \\
\text { impacts, risks of } \\
\text { soil/water if } \\
\text { individualized } \\
\text { parcels }(+/--)\end{array}$ & $\begin{array}{l}\text { Significant possible } \\
\text { implementation concerns, } \\
\text { monitoring and regulation } \\
\text { likely needed for some } \\
\text { approaches }(-)\end{array}$ \\
\hline $\begin{array}{l}\text { 3. Increase allocation of hillsides } \\
\text { and degraded areas for private tree } \\
\text { planting }\end{array}$ & $\begin{array}{l}\text { Potentially large } \\
\text { benefits, up to } 500 \\
\text { EB per capita } \\
\text { increase in income } \\
(++)\end{array}$ & ++ & $\begin{array}{l}\text { Depends on how } \\
\text { wastelands allocated, } \\
\text { could be very important } \\
\text { for landless and land } \\
\text { poor }(? /++)\end{array}$ & $\begin{array}{l}\text { Likely very } \\
\text { positive, with } \\
\text { some risks } \\
(++/-)\end{array}$ & $\begin{array}{l}\text { Easy to implement; though } \\
\text { possible constraint of seedlings } \\
(++/-)\end{array}$ \\
\hline $\begin{array}{l}\text { 4. Allow eucalyptus planting in } \\
\text { farmlands with regulation }\end{array}$ & $\begin{array}{l}\text { Potentially large } \\
\text { benefits, though } \\
\text { probably less than } \\
\text { option } 3 \\
(++)\end{array}$ & $\begin{array}{l}\text { Potential food } \\
\text { security risk } \\
\text { to investors, } \\
\text { but may } \\
\text { benefit others } \\
(+/-)\end{array}$ & $\begin{array}{l}\text { Depends on how } \\
\text { implemented, but could } \\
\text { hurt landless } \\
\text { beneficiaries of option } 3 \\
(? /-)\end{array}$ & $\begin{array}{l}\text { Possible mixed } \\
\text { impacts }(+/-)\end{array}$ & $\begin{array}{l}\text { Need to carefully evaluate and } \\
\text { enforce regulations on } \\
\text { placement of trees (-) }\end{array}$ \\
\hline $\begin{array}{l}\text { 5. Provide or facilitate long-term } \\
\text { credit for tree planting }\end{array}$ & $\begin{array}{l}\text { Potentially large } \\
\text { benefits if combined } \\
\text { with options } 3 \text { or } 4 \\
(++)\end{array}$ & + & $\begin{array}{l}\text { May favor wealthier } \\
\text { landowners, but } \\
\text { indirectly benefit land } \\
\text { poor }(+/-)\end{array}$ & $\begin{array}{l}\text { Similar to } \\
\text { impacts of } \\
\text { options } 3 \text { and } 4 \\
(+/-)\end{array}$ & $\begin{array}{l}\text { Obtaining repayment of loans } \\
\text { might be difficult; should be } \\
\text { cautious, build on DEDEBIT } \\
\text { success (-) }\end{array}$ \\
\hline
\end{tabular}


timber products, and/or encouraging the management of woodlots at the kushet level are policies that allow near-term benefits to be better realized by communities in Tigray.

Planting density and the intensity of labor effort provided to kushet-managed woodlots are greater. This may be because people have more incentive to contribute effort to an investment that is managed and whose benefits are received at a more local level. Consistent with this, survival rates of eucalyptus trees are also higher on kushet woodlots than on tabia woodlots. ${ }^{40}$ These findings suggest that if more community woodlots were managed at the kushet rather than the tabia level, community members might plant trees more densely, emphasize eucalyptus more, devote more effort to their management and achieve higher survival rates (especially of eucalyptus trees).

Improvements in aggregate income and wealth are achieved through exploitation of the main economic benefit of community woodlots, the value of the trees harvested. This benefit can still be exploited if the regional government does not allow the trees to be harvested for a long period of time. However, if rural households discount the future heavily as a result of limited wealth and lack of access to credit, as argued above, the present value of the future harvest of trees to the community may decline as a result of delaying the harvest. For example, based on the economic calculations provided in Table 15 , individuals with a discount rate of $50 \%$ would find investing in eucalyptus highly profitable if they were able to harvest in 5 years and sell the poles at 17 EB (assuming land opportunity cost of $841 \mathrm{~EB} /$ ha and a daily wage rate of $8 \mathrm{~EB}$ ), yielding a $62 \%$ internal rate of return and a positive net present value of 1,270 EB/ha. By contrast, if the same people were forced to wait for 10 years to harvest, they would find the return unprofitable, even if the poles were larger as a result and worth $41 \mathrm{~EB}$. In this case the internal rate of return would be $32 \%$ and the net present value would be $-2,200 \mathrm{~EB} / \mathrm{ha}$. Theoretically, the economic optimum time to harvest trees is when the annual percentage increase in the value of the tree stock (whether due to growth or to price changes) minus

${ }^{40}$ This is mainly due to higher survival rates of E. globulus; survival rates for $E$. camaldulensis are similar in both types of community woodlots (see Table 12). 
the opportunity cost of the land (as a percentage of the value of the tree stock) falls below the discount rate (Pearse 1990).

Local communities may be better placed than the woreda Bureau of Agriculture to judge the optimum time for harvesting trees (perhaps with technical assistance from the Bureau). They likely have better information about growth rates, prices, and opportunity costs of land, as well as knowing better how much they discount the future. Longer harvest cycles determined by the regional government implicitly impose a lower discount rate than the community would use in evaluating the future costs and benefits (for a community that would choose a shorter harvest cycle given the chance). The community is forced to accept a lower rate of return on its investment than it could have earned. Further, low returns, together with the uncertainty caused by regulation of harvesting, likely reduces the incentive of community members to invest in managing community woodlots.

Regulation of woodlot harvesting may reduce food security. When there is a drought or other adverse shock that reduces household incomes, the ability to sell trees could be a valuable source of needed income and a preferable alternative to selling off livestock or suffering hunger. Where communities are prevented from being able to take advantage of this option, food security may be reduced. Beyond the obvious immediate negative impact that this has on the welfare of rural people, it also may undermine their incentive and ability to invest in woodlots, as well as in new crops or technologies that may be risky.

The distribution of benefits from community woodlots may also be affected by regulation of community woodlots. The impacts will depend upon how communities decide to allocate benefits in the absence of regulation. It is possible that more powerful individuals in a community may be able to reap disproportionate benefits while less powerful individuals receive little benefit from woodlots, if communities are completely free to allocate benefits as they wish. However, this seems unlikely to be a major problem, given the relatively equal distribution of land and other resources in Tigray. Still, it may be useful for the regional government to monitor how woodlots are managed 
and how costs and benefits are distributed, even if regulation is reduced, so that potential problems can be identified. The impacts on the distribution of benefits in the case where kushet-managed woodlots are promoted would depend on how kushets would allocate benefits compared to tabias. This issue is worthy of further study.

The ecological impacts of greater community autonomy or promoting kushet management of community woodlots are mixed. To the extent that local communities are not well informed about ecological principles or potential impacts of alternative management approaches, there may be adverse consequences of deregulation. For example, communities may decide to place eucalyptus woodlots too close to water sources or crops without realizing the potential harm that this may cause to local water supplies or crop production. The provision of education and training to communities on management principles and practices is likely to be an effective substitute for regulation if it takes a flexible and participatory approach, responding to the concerns and local situations facing rural people, rather than promoting a blanket set of recommendations to be applied the same in all circumstances.

Where there are ecological or other impacts that extend beyond the boundaries of the community, providing training and education may not be sufficient to solve the problem. For example, if a woodlot in one community is causing water sources for downstream communities to dry up, the community members may not have adequate incentive to address the problem, even if they are aware of it. Intervention by a higher level of government, for example, woreda-level officials may effectively handle issues that arise between tabias, particularly if the affected tabias are part of only one woreda.

Promoting woodlot management at the kushet level may lead to more intensive management practices, including greater planting densities and more frequent harvesting, which may deplete soil and water resources where woodlots are established more rapidly than before. Kushets may also emphasize eucalyptus to the exclusion of other species, reducing biodiversity of woodlots and the availability of other services that are provided by other types of trees. Also, the negative impacts of kushet woodlots on water 
availability and crop production in nearby fields may be greater, if they have higher planting densities.

There can be ecological benefits as well as risks due to deregulation. To the extent that community members have greater incentive to plant and manage trees in woodlots, this may reduce the demand for other sources of biomass such as dung and crop residues, which may lead to improved management of cropland. As the scarcity of wood poles and fuelwood is reduced, other kinds of trees providing other economic and environmental services may become attractive. This can reduce the pressure to deforest remaining forest areas and lead to investments in other tree species, contributing to increased tree cover, additional sources of fodder, greater biodiversity, protection of watersheds, reduced erosion, and other economic and ecological benefits.

Deregulation of community woodlots would decrease the administrative burden on the regional government and place decision-making at lower levels where there is better information about local circumstances and concerns. Although this change would increase the decision-making and administrative requirements at the local level, this would likely be acceptable to people at that level since it provides them greater authority over the use of resources that directly affect their livelihoods and the potential of greater economic returns and food security. Devolving authority over woodlots to kushets would be relatively easy and inexpensive to implement, provided that local tabias and kushets were in favor of the idea. If existing tabia woodlots were devolved to the kushet level, disputes may occur regarding which community members have rights to woodlot benefits. In some cases it may be best to leave management of existing woodlots to tabias. Managing new woodlots at the kushet level would be easier policy to implement, but even here a blanket prescription would probably be unwise.

\section{ALLOCATE PORTIONS OR ALL OF EXISTING COMMUNITY WOODLOTS FOR PRIVATE MANAGEMENT}

Allocating portions or all of existing community woodlots for private use may lead to more intensive land use. Evidence of higher survival rates for eucalyptus trees planted in private woodlots than community woodlots suggests more intensive 
management at the private level. ${ }^{41}$ Privatizing community woodlots would likely have similar kinds of economic and ecological impacts as the preceding option, though the impacts could well be larger (i.e., higher returns, but potential overuse of soil and water resources and negative externalities), since private woodlots appear to be managed more intensively than kushet-managed woodlots. This could lead to management of private woodlots in an unsustainable manner. Also, allocating small parcels of a woodlot to individuals may increase the cost of protecting trees; costs may be much higher than if the woodlot is managed (or at least protected) collectively (Sakurai et al. 1999). However, it may be possible to capitalize on economies of scale in woodlot protection by having some agent of the community (i.e. guard), protecting many small private parcels of land. ${ }^{42}$

There are two potential options for combining the advantage of the economy of scale in protecting a woodlot with the incentive advantage of private management. One option is to separate ownership from management of the woodlot. ${ }^{43}$ This could be done if the community were to hire an agent or small group of agents to manage the woodlot on its behalf. The agent would be responsible for managing the trees on a sustainable basis, and would receive a fixed payment or portion of the proceeds from the woodlot as compensation and incentive for sustainable management. An alternative approach would be to provide the right to manage the woodlot as a franchise to an individual or group based upon a lottery, a bidding process, or some other allocation mechanism. In this case, the manager(s) would pay the community for the right to manage the woodlot, and

${ }^{41}$ Our community survey did not collect information on labor and other input use on private woodlots; this information is being collected as part of a household survey presently being conducted in Tigray.

42 Balanced against this economy of scale, which favors collective protection of resources, is the reduced incentive for effort when the returns from the effort are more broadly shared. If the value of the tree product is high enough and management is intensive, such as may be the case for timber management, the balance may weigh in favor of private management, despite the economy of scale in protection (Sakurai etal. 1999).

${ }^{43}$ This type of system, called centralized management, is used in some natural forests in Nepal, and has been found there to lead to more profitable use of the forest than collective management, and with equally good protection of the forest (Sakurai etal. 1999). 
would receive the benefits from managing the woodlot. Both approaches are likely to reduce the potential negative externalities associated with small private parcels.

The approaches mentioned in the preceding paragraph would differ in the distribution of benefits and risks. With centralized management and fixed payments to agents, the community would be the residual claimant of profits from the woodlot. Thus, the community would receive most of the benefits and bear the risks of poor returns. In the case of a franchise, the franchise holder would receive the residual profits and bear the risks. The case of centralized management with payment of a portion of the proceeds to the managers is an intermediate case, with both the community and the managers receiving a portion of the benefits and bearing a portion of the risks. ${ }^{44}$

Privatization of community woodlots could face substantial obstacles to implementation, particularly if there are individuals or groups in the community that feel that their rights of access have been lost without adequate compensation. This problem would probably be minimal if the existing woodlot were divided up relatively equally and allocated to individual households through a lottery. Given the long experience with and acceptance of cropland distribution by lottery in Tigray, a similar approach for distributing woodlot land for private use might be readily accepted. Implementation problems might be greater for the other approaches to privatization suggested. In the case of centralized management, an important implementation concern could be ensuring adequate monitoring of the managers, so that they provide sufficient effort (particularly

${ }^{44}$ These cases are analogous to private land tenure and labor arrangements. The case of centralized management with fixed payments to agents is analogous to private landowners hiring workers for a fixed wage (the community is analogous to the landowner as the risk bearer); the franchise case is analogous to tenants leasing land for a fixed rent (with the franchise holder bearing the risk as would a tenant); and the case of centralized management with managers receiving a portion of the proceeds is analogous to sharecropping. Thus, as in the case of sharecropping, the third case may be preferred where the managers seek to share their risks with the community (ruling out the franchise model) but the community seeks to provide the managers greater incentive for effort than would be the case with centralized management with a fixed payment (Otsuka and Hayami 1988). 
in the case of fixed payments). Also, how the benefits to the community will be allocated is a concern with centralized management. In the franchise approach, individuals or small groups receiving profits from what had previously been a community resource could be problematic. In addition, there may be concerns about what prices the franchise managers would be permitted to charge for poles, fuelwood, or other materials provided from the woodlot.

As with other cases discussed previously, the success of any of these privatization approaches is likely to be greater if the approach is chosen by the local community, rather than imposed from above. The role of the regional government may be more effective as one of providing information and guidance, rather than mandates to local communities.

\section{INCREASE ALLOCATION OF HILLSIDES AND DEGRADED LANDS FOR PRIVATE TREE PLANTING}

The Tigray Region Bureau of Agriculture is presently studying the possibility of allowing communities to allocate hillsides and degraded lands for private tree planting or other conservation uses. It is pilot-testing this approach in a small number of villages. However, some communities are implementing this approach on their own: twelve of fifty tabias surveyed had allocated lands for private tree planting. Nevertheless, this approach could be significantly expanded if the regional Bureau decides to promote it.

The economic benefits of expanded private tree planting on hillsides and degraded areas could be very large. Based on data provided by the Tigray Bureau of Agriculture and Natural Resources, there are an estimated 334,000 hectares of wasteland in the highlands of Tigray. If this area were allocated for private tree planting, eucalyptus trees were planted with the same density as the median found on private woodlots in our survey (about 3000 trees per ha.) and survived at the same rate (71 percent), that would amount to about 710 million eucalyptus trees surviving. If these trees were cut for poles worth $17 \mathrm{~EB}$ (the minimum price found in any region in 1998), every 10 years, the return would be about 370 EB per capita in Tigray. This is almost half of the per capita Gross Domestic Product in Ethiopia in 1998 (750 EB/capita) (IMF, 2000). Assuming a social discount rate of $10 \%$, the social net present value of this investment (using the 
assumptions about labor input as in Table 13) would be about 2,000 EB per capita. Clearly, even if not all (but a significant fraction of) wastelands were used for tree planting, or even if pole prices were to fall below $17 \mathrm{~EB}$, the potential economic impact of allocating wastelands for private tree planting would still be very large.

The impact of such a substantial increase in wealth and income on food security would undoubtedly also be substantial. Besides the direct effect of increased incomes, having such a stock of valuable and marketable assets would increase households' ability to cope with shortfalls in crop production or income. In addition, if landless and land poor people are recipients of wastelands, this would increase their ability to achieve food security even if they are unable to acquire sufficient land to meet their food needs through their own crop production. Landless and land poor people may also find it easier to earn income from off-farm employment while maintaining their woodlots, compared to the difficulty of trying to work off-farm while producing crops since the labor to manage private woodlots would be needed mainly for planting and watering activities in the first few years. Allocation of wasteland to the landless may also help reduce pressure on communities to pursue cropland redistribution, which can have negative impacts on farmers' incentives to invest in land improvements on cropland.

The ecological impacts of tree planting on hillsides and degraded lands are also likely to be positive. Increased biomass, greater recycling of organic material to the soil, watershed protection, and reduced erosion on barren hillsides, is likely to occur, and the magnitude of these benefits greater than the previous policy option of privatizing community woodlots. There could be negative indirect effects on community woodlots if community members begin to devote less attention to managing those in favor of investing in private woodlots. And there may be negative consequences for water supplies or crop production if private woodlots are established too close to water sources or crops. Thus, some training and monitoring by governmental authorities appears warranted for this option, as for the previous options. With appropriate and limited oversight, the potential ecological benefits would appear to far outweigh the potential costs, though this should be studied further. 
This policy option would be easy and inexpensive to implement, since it mainly involves allowing local communities to pursue this option where it is feasible and appropriate for them. One potential constraint to rapid expansion of private tree planting could prove to be the availability of seedlings. Although this has not been a constraint to date (as we have found in our community survey), expanding tree planting to most of the wastelands in Tigray could strain the ability of seedling supply to keep pace with demand. The regional government should consider increasing the number of government nurseries, or promoting private nurseries, if it decides to pursue this option. The development of local nurseries could be particularly important for more remote areas.

\section{ALLOW EUCALYPTUS PLANTING IN FARMLANDS WITH REGULATION}

The most radical policy option (in terms of deviation from current policy) would be to allow eucalyptus planting in farmlands. As with the option of expanding private tree planting on wastelands, this option has the potential to cause a large increase in the number of eucalyptus trees planted in Tigray, having a potentially large economic impact, though the net benefit may be less than the policy of planting eucalyptus on wastelands due to the opportunity costs of land converted from crop production to eucalyptus production. We would expect farmers to replace crops by eucalyptus only if the benefits of doing so exceed the costs. As our earlier estimates suggest, there are likely to be many places where the benefits do exceed the costs, given the low productivity of crops and the scarcity of tree products in much of Tigray. ${ }^{45}$

Since eucalyptus trees take several years to mature, there is a risk that wood prices may fall substantially between the time farmers decide to plant them and the time

${ }^{45}$ Benefits may exceed costs until the supply of woodlot products has expanded sufficiently to bring the price of poles, fuelwood and other woodlot products down substantially, and the benefits of additional tree planting are no greater than the opportunity cost of land. We do not have the data to estimate what level of eucalyptus production or price of poles would bring about this equilibrium, though it is likely to be at a substantially higher level of production than exists today, given the high returns to eucalyptus production at present. 
that they can be harvested. This risk is particularly important to consider for farmers who may replace crop production by tree planting, since they can become food insecure if the value of the trees falls too low. Also, once eucalyptus becomes established in farmland, it may be very costly to return those lands to crop production later if eucalyptus turns out to be unprofitable. Thus, some caution on the part of farmers is warranted before planting eucalyptus in farmlands (even if this is expected to be profitable), particularly if they do not have access to other secure sources of income. The regional government could play a valuable role in educating farmers about these risks, if this option is pursued. Rather than allowing eucalyptus in all farmlands, the regional government could decide to allow limited eucalyptus planting in farmlands; for example, as a windbreak.

A change in the current policy may offer substantial benefits for households that are willing to accept these risks (particularly those with significant off-farm opportunities and income). On the other hand, landless and land-poor households may be little able to take advantage of this option, and could be hurt indirectly (along with others) by the reduction in wood prices that would result if both this option and the option to allocate wastelands for private tree planting were pursued. If the option of allowing tree planting on wastelands is adopted, it would be prudent to commit to continuing the ban on eucalyptus plating on farmlands for a relatively long period of time (at least 10 years), thus allowing investors in private tree planting some certainty about the future policy and price environment.

To be seriously considered by policy makers, such an option would probably have to include regulation of the placement of trees on fields. Rather than an outright ban on eucalyptus in farmlands, it might be possible to attain the benefits of expanded eucalyptus planting in farmlands with minimal negative externalities if suitable regulations are adopted. For example, farmers could be allowed to plant eucalyptus in farmlands but could be required to plant them a minimum distance from other farmers' fields and water sources. As was pointed out in earlier section, there may be positive impacts associated with planting eucalyptus in farmlands. Trees in cropland may reduce water and wind erosion, and they may also reduce runoff and evaporative losses of water. Thus, depending 
upon the local circumstances and the nature and enforcement of the regulations, the ecological benefits of allowing trees in farmlands may outweigh the ecological damages.

There is also a need to address the concerns of farmers and policy makers about the negative impacts of planting eucalyptus. If this policy is seriously considered, this issue should be studied carefully, based upon review of the existing evidence and perhaps new studies conducted in the highlands of Tigray to measure the negative impacts of eucalyptus in that environment. It would also be useful to use a consultative process to develop the regulations, seeking input from communities and households in different parts of Tigray, as well as from forestry experts and others.

\section{FACILITATE ACCESS TO LONG-TERM CREDIT AND OTHER FACTORS FAVORING TREE PLANTING}

The final option that we consider is for the regional government to facilitate the availability of long-term credit and other factors (such as development of nurseries, roads, education and training) that would promote tree planting and marketing. If medium to long-term credit could be made available, even at significantly higher interest rates than currently charged for formal credit, this may attract many more people to invest in tree planting. The government might provide a line of credit for this directly, or provide guarantees to encourage private lenders to provide such credit.

The impacts of providing long-term credit would likely be limited unless it were combined with one or more of the policy options already presented. The impact of access to long-term credit would probably be greatest in areas close to urban markets where the potential market return from eucalyptus planting would be highest, and where potential investors may be inhibited by family labor constraints from large labor-intensive eucalyptus planting efforts (especially if family members are employed in off-farm activities). In this type of a situation, the availability of credit could help to finance labor hiring to help during the first few years of intensive planting and management of the trees. In areas where the market for tree products is less robust and local labor availability is less of a constraint, credit may be less necessary to finance tree planting 
and management, though it still could be helpful. Development of local nurseries, education and training could still be quite important in such areas, however.

The direct impacts of credit would favor landowners who would be inclined to hire workers to help with tree planting and management. This could tend to favor wealthier households, though it may also help households with limited labor and/or oxen (such as female headed households) to develop an alternative to crop or livestock production as a major source of income and food security. Credit for tree planting would likely indirectly promote labor demand and thus tend to increase the rural wage rate, which would be beneficial to landless and land poor households dependent upon rural wage income. Thus this option could be beneficial for the poorest households, even if they did not use the credit directly.

The type and direction of ecological impacts of this option would be similar to the impacts of the options to facilitate private tree planting, discussed above. In the long run, if credit and tree planting enabled households to satisfy their short-term needs more easily and to increase their wealth status significantly, we could expect households' discount rates to decline, as predicted by the work of Pender (1996) in India and Holden, et al. (1998) in Ethiopia. This could have major ecological benefits as rural households become more able to take the future into account in their agricultural management and investment decisions. ${ }^{46}$

Providing long-term credit might prove difficult to implement, depending upon how difficult it would be to obtain repayment of the loans. The approach could build upon the success of REST's and DEDEBIT's credit schemes, which have had a strong record of obtaining repayment through a group lending approach. However, use of that approach has been mainly for relatively short-term loans (typically less than one year term) and its effectiveness in long-term loans of the kind that would be needed for tree

${ }^{46}$ For example, other types of investments that are unlikely to be attractive to households with high discount rates, such as soil and water conservation measures or other types of slower-growing trees, may become attractive as households' discount rates decline. 
planting (probably at least 5-year loans) has not been widely demonstrated. One approach that has been used by the Grameen Bank in Bangladesh for long-term housing credit is to link the availability of such credit to a substantial period of successful repayment performance for shorter loans (Manohar Sharma, personal communication). After borrowers demonstrate their credit-worthiness over a period of, say, four or five years, they are considered qualified for longer-term loans. The Grameen Bank has been able to obtain high repayment rates with this approach (Ibid.), and a similar approach might work well in Tigray. Since the REST and DEDEBIT credit programs have now been operable for many years and have obtained good repayment, they should be able to identify many credit-worthy applicants for longer-term credit from their clientele. ${ }^{47}$

Implementation of the other aspects of this option (building roads, establishing nurseries, education and training) would also entail investment costs. The regional government may defer to local priorities concerning which, if any, of these areas to invest in, but a broad sense of the priorities for investment could be based on consideration of where the social rates of return to investment in tree planting would be greatest. Based upon considerations discussed earlier in this paper, this is probably in areas of relatively good access to markets, low population density (especially where substantial wastelands exist), reasonable access to water for seedlings and not at too high an elevation for eucalyptus to grow rapidly. There are many areas in Tigray that meet most of these criteria.

\section{CONCLUSIONS AND IMPLICATIONS}

We have reviewed the literature on the ecological impacts of eucalyptus trees and found that these impacts are complex, mixed, and dependent upon local conditions. In a moisture-stressed environment such as in most of northern Ethiopia, there are good

${ }^{47}$ To pursue this option, the regional government of Tigray could encourage DEDEBIT to pilot test the approach in a few places. It would be prudent to investigate whether strong repayment performance could be expected from the approach before adopting it on a large scale. 
reasons to be concerned about the negative impacts that eucalyptus trees may have on crop production and water sources, as a result of their capacity to compete for water, light and plant nutrients, and their allelopathic effects. However, there are also many potential ecological benefits associated with planting eucalyptus due to their ability to grow rapidly and thrive in such an environment, including reducing runoff and erosion (both by water and wind), providing scarce biomass, reducing pressure on natural forests, and being able to survive threats caused by fire, pests and diseases. Whether the ecological benefits outweigh the costs will depend on many factors specific to the local situation, such as the availability of rainfall and soil moisture, the risk of excessive runoff and erosion, the scarcity of land and biomass, and the alternative sources of timber and energy available to households. It is not advisable to make decisions about the use of eucalyptus based on consideration of only the negative or of the positive impacts, or without also considering the reasons why poor households choose to plant these trees and the economic impacts that these trees may have on the welfare of households.

The main factors influencing households' and communities' decisions to invest in eucalyptus or other trees are expected to be those that determine the costs and returns of these investments, including the opportunity costs and availability of land, labor and other inputs; the cost and availability of seedlings; the rate of growth of the trees; the price (or local scarcity, if not marketed) of poles, fuelwood and other tree products; the discount rate of households; and the institutional factors affecting the ability of households to receive benefits, the distribution and timing of benefits and costs; and the ability to attain effective collective action (especially for community woodlots). Based upon these considerations, we hypothesize that tree planting activities are most profitable in areas where population density is low, land of low agricultural potential (but still suitable for eucalyptus) is readily available, access to markets with elastic demand for tree products is high, there is access to long-term credit or households are wealthier and thus have lower discount rates, and where decisions about tree planting, management and use are made at a more local level (i.e., by private individuals or villages, as opposed to higher administrative levels). 
We explored these hypotheses using data from a survey in Tigray to estimate the costs and benefits of eucalyptus under different circumstances in the region. We found that eucalyptus generally yields a high-expected rate of return, well above $20 \%$ in most circumstances. The most important factors influencing the rate of rate of return are the harvesting period and the opportunity cost of land (the latter especially where eucalyptus is planted in farmland). Observed variations in eucalyptus pole prices and labor costs also have significant, though less important effects. Woodlots that are managed by villages or private individuals are estimated to yield higher rates of return than those managed at a higher administrative level, due to greater management intensity and higher survival rates of trees. The economic impact of eucalyptus planting in farmlands on reducing crop production on neighboring farmers' fields was found to be relatively small compared to the benefits received by the investor.

These findings suggest that increased benefits from tree planting efforts will be possible by allowing households and communities to harvest the trees sooner than has been the case until now in Tigray, by allowing tree planting on lands of low opportunity costs, such as hillsides and degraded areas, and by encouraging management of trees at the household or village level. The fact that the rates of return to eucalyptus are generally well above real interest rates for formal sector credit, though likely below the discount rates of many poor households, suggests also that efforts to address financial constraints by facilitating the availability of long-term credit to finance tree planting and management activities may also substantially increase the attractiveness of such investments. The limited economic costs of eucalyptus planting in farmlands to neighboring farmers, relative to the benefits, does not mean that such external costs should not be of concern, but it does suggest that an alternative to an outright ban on such planting may be able to minimize these costs (or compensate the affected neighbors) while allowing substantial economic benefits to be realized.

These implications motivate the options to amend current policy in Tigray that we considered. Among the options discussed, the most promising, for socioeconomic and ecological reasons as well as the ease of implementation, appears to be allowing 
communities to allocate hillsides and degraded lands for private (or village-managed) tree planting. Allowing regulated planting of eucalyptus on farmlands could also yield large economic benefits, but also carries substantial economic and ecological risks. If the option of allocating wastelands for tree planting is pursued, it may be prudent to continue the current ban on eucalyptus in farmlands for an extended period of time, at least until the impacts of wasteland allocation become clearer and investors in such woodlots have a chance to recoup the initial returns of their investments.

Most of the other options discussed could also be pursued at the same time, and all offer significant economic benefits compared to current policy. Among these, increasing the authority of local communities to manage and use community woodlots and encouraging management of community woodlots at the village level, would be fairly easy to implement and offer potential to significantly increase the benefits provided by community woodlots. Privatizing existing community woodlots would be more difficult, and may not yield large benefits compared to allowing greater local authority and encouraging management at the village level. Nevertheless, such choices may be best left up to local communities to decide. In general, all of the options considered are more easy to implement and more likely to be effective if they are not imposed upon local communities, but rather chosen by communities as part of a consultative process.

The effectiveness of all of these options can be enhanced by complementary policies and investments, such as facilitating the availability of long-term credit and local nurseries, providing education and training on sustainable woodlot management, and investing in infrastructure such as roads in areas with significant potential for commercial tree production and marketing.

Some of the results of this study are based upon limited information, particularly regarding the management of private woodlots and the pattern of investments in woodlots and returns over time. In addition, we have not included non-monetary costs and benefits in our estimates of rates of return, and as we have seen, the ecological impacts can be quite complex and varied from one location to the next. More research on these issues is warranted. 


\section{REFERENCES}

Anderson, D. 1987. The economics of afforestation: A case study in Africa. Occasional Paper Number 1. Washington, D.C.: World Bank.

Armitage, J. and G. Schramm. 1989. Managing the supply of and demand for fuelwood in Africa. In Environmental management and economic development, ed. G. Schramm and J.J. Warford. Baltimore and London: The Johns Hopkins University Press.

Arnold, J.E.M. 1984. Economics constraints and incentives in agroforestry. In Social, economic and institutional aspects of agroforestry, ed. J.K. Jackson. Tokyo: United Nations University.

Atkinson, P.R., K.M. Nixon, and M.J.P. Shaw. 1992. On the susceptibility of Eucalyptus species and close to attack by Macrotermes natalensis Haviland (Isoptera: Termitidae). Forest Ecology and Management 48:15-30.

Bacon, P.E., C. Stone, C.L. Binns, D.J. Leslie, and E.W. Edwards. 1993. Relationships between water availability and Eucalyptus camaldulensis growth in a riparian forest. Journal of Hydrology (Amsterdam) 150:541-561.

Bekele-Tesemma, A. 1997. A participatory agroforestry approach for soil and water conservation in Ethiopia. Tropical Resource Management Papers No.17. Wageningen: Wageningen Agricultural University.

Blandon, P. 1985. Agroforestry and portfolio theory. Agroforestry Systems 3: 239-249.

Böjo, J. and D. Cassells. 1995. Land degradation and rehabilitation in Ethiopia: A reassessment. AFTES Working Paper No.17. Washington, D.C.: World Bank.

Bristow, S. 1995. Agroforestry and community-based forestry in Eritrea. Working Paper No.2. Washington, D.C.: World Bank.

Bruce, J., A. Hoben, and D. Rahmato. 1994. After the Derg: An assessment of rural land tenure issues in Ethiopia. Madison: Land Tenure Center, University of Wisconsin at Madison.

Bruijnzeel, L.A. 1990. Hydrology of moist tropical forests and effects of conservation: A state of knowledge review. Amsterdam: Netherlands Committee for the International Hydrological Programme of UNESCO.

Bureau of Agriculture and Natural Resource Development (BoANRD). 1996. Tigray Forestry Action Program (Volume I). Mekelle, Ethiopia. 
Calder, I.R., R.K. Hall, and K.T. Prasanna. 1993. Hydrological impact of Eucalyptus plantation in India. Journal of Hydrology (Amsterdam) 150: 635-648.

Cassells, D.S., M. Bonell, S. Hamilton, and D.A. Gilmour. 1987. The protective role of tropical forests: A state of knowledge review. In Agroforestry in the humid tropics: Its protective and ameliorative role to enhance productivity and sustainability, eds. N.T. Vergara and N.D. Briones. Honolulu: Environment and Policy Institute, East-West Center.

Cernea, M. 1981. Land tenure systems and social implications of forestry development programs. World Bank Staff Working Paper No.452. Washington D.C.: World Bank.

Choudhury, K. and L.J.M. Jansen. 1998. Terminology for integrated resources planning and management. Rome: Food and Agriculture Organization of the United Nations.

Council of the National State of Tigray. 1997. The National State of Tigray-Rural Land Proclamation No. 23/1997. Mekelle: Council of the National State of Tigray.

Dewees, P. and N. Saxena. 1997a. Tree planting and household land and labor allocation: Case studies from Kenya and India. In Farms, trees and farmers, edS. J.E.M. Arnold and P. Dewees. London: Earthscan Publications Ltd.

. 1997b. Wood product markets as incentives for farmer tree growing. In Farms, trees and farmers, eds. J.E.M. Arnold and P. Dewees. London: Earthscan Publications Ltd.

EFAP. 1993. Ethiopian forestry action programme: Final report. Addis Ababa: Ministry of Natural Resource Development and Environmental Protection.

FAO (Food and Agriculture Organization of the United Nations). 1979. Eucalyptus for planting. Rome: FAO.

. 1985. The ecological effects of Eucalyptus. FAO Forestry Paper No.59. Rome. . 1986. Highlands reclamation study: Ethiopia. Final Report. Rome.

1992. Economic assessment of forestry project impacts. FAO Forestry Paper No. 106. Rome:

. 1998. Ethiopia: Soil fertility initiative-Concept paper. Rome.

Filius, A.M. 1982. Economic aspects of agroforestry. Agroforestry Systems 1: 347-360. 
Gebremedhin, B. 1998. The economics of soil conservation investments in the Tigray region of Ethiopia. Ph.D. diss., Michigan State University, East Lansing, Michigan.

Gebremedhin, B., J. Pender, and G. Tesfaye. 1999. Community natural resource management: The case of woodlots in Northern Ethiopia. Contributed Paper to be presented at the XXIV International Conference of Agricultural Economists, Berlin, August 2000.

Gregersen, H.S. Draper, and D. Elz, eds. 1989. People and trees: The role of social forestry in sustainable development. Washington, D.C.: World Bank.

Grewal, S.S., S.P. Mittal, S. Dyal, and Y. Agnihotri. 1992. Agroforestry systems for soil and water conservation and sustainable production from foothill areas of north India. Agroforestry Systems 17: 183-191.

Hagos, F., J. Pender, and N. Gebreselassie. 1999. Land degradation in the highlands of Tigray and strategies for sustainable land management. Socioeconomic and Policy Research Working Paper No.25, Livestock Policy Analysis Project. Addis Ababa: International Livestock Research Institute.

Henry, P.W.T. 1973. Notes on maps of the Eucalyptus plantations around Addis Ababa and Menagesha State Forest. ODA Miscellaneous Report No.150. London: Overseas Development Assistance.

Hoben, A. 1996. The cultural construction of environmental policy: Paradigms and politics in Ethiopia. In The lie of the land: Challenging received wisdom on the African environment, eds. M. Leach and R. Mearns. Portsmouth: Heinemann.

Holden, S.T., B. Shiferaw, and M. Wik. 1998. Poverty, market imperfections and time preferences: Of relevance for environmental policy? Environment and Development Economics 3: 105-130.

Huchu, P. and P.N. Sithole. 1993. Rates of adoption of new technology and climatic risk in the communal areas of Zimbabwe. In Soil fertility and climatic constraints in dryland agriculture. ADIAR Proceedings No. 54. Canberra: Australian Centre for International Agricultural Research.

IMF (International Monetary Fund). 2000. International financial statistics. March.

Kappel, W. 1996. Economic analysis of soil conservation in Ethiopia: Issues and research perspectives. Center for Development and Environment, University of Bern. Cited in Ethiopia: Soil fertility initiative concept paper. Rome: FAO. 
Jagger, P. 1999. An economic analysis of afforestation in rural Zimbabwe. MSc. thesis, University of Alberta, Edmonton, Alberta, Canada.

Jodha, N.S. 1986. Common property resources and rural poor in dry regions of India. Economic and Political Weekly XXI (27): 1169-1181.

Lacey, C.J. 1974. Rhizomes in tropical eucalyptus and their role in recovery from fire damage. Australian Journal of Botany 22: 28-38.

Lisanework, N. and A. Michelsen. 1993. Allelopathy in agroforestry systems: The effects of leaf extracts of cupressus lusitanica and three eucalyptus spp. on four Ethiopian crops. Agroforestry Systems 21(1): 63-74.

Livingstone, I. 1986. The common property problem and pastoralist economic behavior. Journal of Development Studies 23 (10): 5-19.

Malik, R.S. and S.K. Sharma. 1990. Moisture extraction and crop yield as a function of distance in a row of eucalyptus tereticornis. Agroforestry Systems 12: 187-195.

Mandondo, A. 1995. Ownership and management of eucalyptus camaldulensis woodlots in northeastern Zimbabwe. Suid-Afrikaanse Bosboutydskrif 174 (Nov.): 9-15.

May, F. and J. Ash. 1990. An assessment of the allelopathic potential of Eucalyptus. Australian Journal of Botany 38: 245-254.

Mazodze, R. 1990. Review of forest entomology. In Proceedings of the anniversary seminar 'Forest research in Zimbabwe'. Harare: Zimbabwean Forestry Commission.

McCann, J.C. 1995. People of the plow-An agricultural history of Ethiopia. Madison: University of Wisconsin Press.

Michelsen, A., N. Lisanework, and I.Friis. 1993. Impacts of tree plantations in the Ethiopian highland on soil fertility, shoot and root growth, nutrient utilization and mycorrhizal colonization. Forest Ecology and Management 61: 299-324.

Mink, S. 1993. Poverty and the environment. Finance and Development (December).

Newcombe, K.J. 1989. An economic justification for rural afforestation: The case of Ethiopia. In Environmental management and economic development, eds. G. Schramm, and J.J. Warford. Baltimore and London: Johns Hopkins University Press.

Otsuka, K. and Y. Hayami. 1988. Theories of share tenancy: A critical survey. Economic Development and Cultural Change 37(1): 31-68. 
Pearse, P.H. 1990. Introduction to forest economics. Vancouver: University of British Columbia Press.

Pender, J. 1996. Discount rates and credit markets: Theory and evidence from rural India. Journal of Development Economics 50: 257-296.

Pohjonen, V. and T. Pukkala. 1990. Eucalyptus globulus in Ethiopian forestry. Forest Ecology and Management 36: 19-31.

Poschen-Eiche, P. 1987. The application of farming systems research to community forestry: A case study in the Hararge Highlands, Eastern Ethiopia. Tropical Agriculture 1. Weikersheim, Germany: Scientific Books.

Price, C. 1989. The theory and application of forest economics. Cornwall: T.J. Press Ltd.

REST (Relief Society of Tigray). 1995. Farming systems, resource management and household coping strategies in Northern Ethiopia-Report of a social and agroecological baseline study in Central Tigray. Mekelle.

Rocheleau, D., F. Weber, and A. Field-Juma. 1988. Agroforestry in dryland Africa. Nairobi: ICRAF.

Runge, C.F. 1992. Common property and collective action in economic development. In Making the commons work: Theory, practice and policy, ed. D.W. Bromley. San Francisco: ICS Press.

Sakurai, T., Y. Kijima, R. Pokharel, S. Rayamajhi, and K Otsuka. 1999. Timber forest management in Nepal and Japan. In Land tenure and natural resource management, eds. K. Otsuka and F. Place. Book manuscript. Washington, D.C.: International Food Policy Research Institute.

Sanginga, N. and M.J. Swift. 1992. Nutritional effects of eucalyptus litter on the growth of maize (Zea mays). Agriculture, Ecosystems and Environment 41: 55-65.

Saxena, N.C. 1991. Crop losses and their economic implications due to growing of eucalyptus on field bunds-A pilot study. Agroforestry Systems 16: 231-245.

Sedjo, R. A. 1983. The comparative economics of plantation forestry: A global assessment. Washington, D.C.: Resources for the Future.

Stiles, D., V.M. Pohjonen, and F. Weber. 1991. Reforestation: The Ethiopian experience, 1984-1989. Technical Support Division of UNSO (United Nations SudanoSahelian Office). New York: UNSO. 
Sutcliffe, J.P. 1993. Economic assessment of land degradation in the Ethiopian highlands: A case study. Addis Ababa: National Conservation Strategy Secretariat, Ministry of Planning and Economic Development, Transitional Government of Ethiopia.

Tiarks, A., E.K.S. Nambiar, and C. Cossalter. 1998. Site management and productivity in tropical forest plantations. Occasional Paper No.16. Bogor: Center for International Forestry Research.

UNDP/ECA. 1994. Sustainable agriculture and environmental rehabilitation in Tigray (SAERT). Statistical Master Book of Tigray, Volume XIII. UNDP/ECA Project Eth. 93/004/A/01/99.

Verinumbe, I. 1987. Crop production on soil under some forest plantations in the Sahel. Agroforestry Systems 5: 185-188.

Wade, R. 1992. Common property resource management in south Indian villages. In Making the commons work: Theory, practice and policy, ed D.W. Bromely. San Francisco: ICS Press.

Weirsum, K. 1984. Surface erosion under various tropical agroforestry systems. In Proceedings of the IFRO Symposium on effects of forest land use on erosion and slope stability, eds. C. O'Loughlin and A. Pearce. Honolulu: Environment and Policy Institute of the East-West Center. 


\section{List of EPTD Discussion Papers}

01 Sustainable Agricultural Development Strategies in Fragile Lands, by Sara J. Scherr and Peter B.R. Hazell, June 1994.

02 Confronting the Environmental Consequences of the Green Revolution in Asia, by Prabhu L. Pingali and Mark W. Rosegrant, August 1994.

03 Infrastructure and Technology Constraints to Agricultural Development in the Humid and Subhumid Tropics of Africa, by Dunstan S.C. Spencer, August 1994.

04 Water Markets in Pakistan: Participation and Productivity, by Ruth MeinzenDick and Martha Sullins, September 1994.

05 The Impact of Technical Change in Agriculture on Human Fertility: Districtlevel Evidence from India, by Stephen A. Vosti, Julie Witcover, and Michael Lipton, October 1994.

06 Reforming Water Allocation Policy Through Markets in Tradable Water Rights: Lessons from Chile, Mexico, and California, by Mark W. Rosegrant and Renato Gazmuri S., October 1994.

07 Total Factor Productivity and Sources of Long-Term Growth in Indian Agriculture, by Mark W. Rosegrant and Robert E. Evenson, April 1995.

08 Farm-Nonfarm Growth Linkages in Zambia, by Peter B.R. Hazell and Behjat Hojjati, April 1995.

09 Livestock and Deforestation in Central America in the 1980s and 1990s: A Policy Perspective, by David Kaimowitz (Interamerican Institute for Cooperation on Agriculture), June 1995.

10 Effects of the Structural Adjustment Program on Agricultural Production and Resource Use in Egypt, by Peter B. R. Hazell, Nicostrato Perez, Gamal Siam and Ibrahim Soliman, August 1995.

11 Local Organizations for Natural Resource Management: Lessons from Theoretical and Empirical Literature, by Lise Nordvig Rasmussen and Ruth Meinzen-Dick, August 1995. 
Competitiveness in Japanese Rice Markets, by Shoichi Ito, Mark W. Rosegrant, and Mercedita C. Agcaoili-Sombilla, August, 1995.

13 Role of Inputs, Institutions, and Technical Innovations in Stimulating Growth in Chinese Agriculture, by Shenggen Fan and Philip G. Pardey, September 1995.

14 Investments in African Agricultural Research, by Philip G. Pardey, Johannes Roseboom, and Nienke Beintema, October 1995.

15 Role of Terms of Trade in Indian Agricultural Growth: A National and State Level Analysis, by Peter B. R. Hazell, V. N. Misra and Behjat Hojjati, December 1995.

16 Policies and Markets for Non-Timber Tree Products, by Peter A. Dewees and Sara J. Scherr, March 1996.

17 Determinants of Farmers' Indigenous Soil and Water Conservation Investments in India's Semi-Arid Tropics, by John Pender and John Kerr, August 1996.

18 Summary of a Productive Partnership: The Benefits from U.S. Participation in the CGIAR, by Philip G. Pardey, Julian M. Alston, Jason E. Christian and Shenggen Fan, October 1996.

19 Crop Genetic Resource Policy: Towards a Research Agenda, by Brian D. Wright, October 1996.

20 Sustainable Development of Rainfed Agriculture in India, by John M. Kerr, November 1996.

21 Impact of Market and Population Pressure on Production, Incomes and Natural Resources in the Dryland Savannas of West Africa: Bioeconomic Modeling at the Village Level, by Bruno Barbier, November 1996.

22 Why do Projections on China's Future Food Supply and Demand Differ? by Shenggen Fan and Mercedita Agcaoili-Sombilla, March 1997.

23 Agroecological Aspects of Evaluating Agricultural R\&D, by Stanley Wood and Philip G. Pardey, March 1997. 
24 Population Pressure, Land Tenure, and Tree Resource Management in Uganda, by Frank Place and Keijiro Otsuka, March 1997.

25 Should India Invest More in Less-favored Areas? by Shenggen Fan and Peter Hazell, April 1997.

26 Population Pressure and the Microeconomy of Land Management in Hills and Mountains of Developing Countries, by Scott R. Templeton and Sara J. Scherr, April 1997.

27 Population Land Tenure, and Natural Resource Management: The Case of Customary Land Area in Malawi, by Frank Place and Keijiro Otsuka, April 1997.

28 Water Resources Development in Africa: A Review and Synthesis of Issues, Potentials, and Strategies for the Future, by Mark W. Rosegrant and Nicostrato D. Perez, September 1997.

29 Financing Agricultural R\&D in Rich Countries: What's Happening and Why, by Julian M. Alston, Philip G. Pardey, and Vincent H. Smith, September 1997.

30 How Fast Have China's Agricultural Production and Productivity Really Been Growing? by Shenggen Fan, September 1997.

31 Does Land Tenure Insecurity Discourage Tree Planting? Evolution of Customary Land Tenure and Agroforestry Management in Sumatra, by Keijiro Otsuka, S. Suyanto, and Thomas P. Tomich, December 1997.

32 Natural Resource Management in the Hillsides of Honduras: Bioeconomic Modeling at the Micro-Watershed Level, by Bruno Barbier and Gilles Bergeron, January 1998.

33 Government Spending, Growth and Poverty: An Analysis of Interlinkages in Rural India, by Shenggen Fan, Peter Hazell, and Sukhadeo Thorat, March 1998, Revised December 1998.

34 Coalitions and the Organization of Multiple-Stakeholder Action: A Case Study of Agricultural Research and Extension in Rajasthan, India, by Ruth Alsop, April 1998. 
35 Dynamics in the Creation and Depreciation of Knowledge and the Returns to Research, by Julian Alston, Barbara Craig, and Philip Pardey, July 1998.

36 Educating Agricultural Researchers: A Review of the Role of African Universities, by Nienke M. Beintema, Philip G. Pardey, and Johannes Roseboom, August 1998.

37 The Changing Organizational Basis of African Agricultural Research, by Johannes Roseboom, Philip G. Pardey, and Nienke M. Beintema, November 1998.

38 Research Returns Redux: A Meta-Analysis of the Returns to Agricultural R\&D, by Julian M. Alston, Michele C. Marra, Philip G. Pardey, and T.J. Wyatt, November 1998.

39 Technological Change, Technical and Allocative Efficiency in Chinese Agriculture: The Case of Rice Production in Jiangsu, by Shenggen Fan, January 1999.

40 The Substance of Interaction: Design and Policy Implications of NGOGovernment Projects in India, by Ruth Alsop with Ved Arya, January 1999.

41 Strategies for Sustainable Agricultural Development in the East African Highlands, by John Pender, Frank Place, and Simeon Ehui, April 1999.

42 Cost Aspects of African Agricultural Research, by Philip G. Pardey, Johannes Roseboom, Nienke M. Beintema, and Connie Chan-Kang, April 1999.

43 Are Returns to Public Investment Lower in Less-favored Rural Areas? An Empirical Analysis of India, by Shenggen Fan and Peter Hazell, May 1999.

$44 \quad$ Spatial Aspects of the Design and Targeting of Agricultural Development Strategies, by Stanley Wood, Kate Sebastian, Freddy Nachtergaele, Daniel Nielsen, and Aiguo Dai, May 1999.

45 Pathways of Development in the Hillsides of Honduras: Causes and Implications for Agricultural Production, Poverty, and Sustainable Resource Use, by John Pender, Sara J. Scherr, and Guadalupe Durón, May 1999. 
46 Determinants of Land Use Change: Evidence from a Community Study in Honduras, by Gilles Bergeron and John Pender, July 1999.

47 Impact on Food Security and Rural Development of Reallocating Water from Agriculture, by Mark W. Rosegrant and Claudia Ringler, August 1999.

48 Rural Population Growth, Agricultural Change and Natural Resource Management in Developing Countries: A Review of Hypotheses and Some Evidence from Honduras, by John Pender, August 1999.

49 Organizational Development and Natural Resource Management: Evidence from Central Honduras, by John Pender and Sara J. Scherr, November 1999.

50 Estimating Crop-Specific Production Technologies in Chinese Agriculture: A Generalized Maximum Entropy Approach, by Xiaobo Zhang and Shenggen Fan, September 1999.

51 Dynamic Implications of Patenting for Crop Genetic Resources, by Bonwoo Koo and Brian D. Wright, October 1999.

52 Costing the Ex Situ Conservation of Genetic Resources: Maize and Wheat at CIMMYT, by Philip G. Pardey, Bonwoo Koo, Brian D. Wright, M.Eric van Dusen, Bent Skovmand, and Suketoshi Taba, October 1999.

53 Past and Future Sources of Growth for China, by Shenggen Fan, Xiaobo Zhang, and Sherman Robinson, October 1999.

54 The Timing of Evaluation of Genebank Accessions and the Effects of Biotechnology, by Bonwoo Koo and Brian D. Wright, October 1999.

55 New Approaches to Crop Yield Insurance in Developing Countries, by Jerry Skees, Peter Hazell, and Mario Miranda, November 1999.

56 Impact of Agricultural Research on Poverty Alleviation: Conceptual Framework with Illustrations from the Literature, by John Kerr and Shashi Kolavalli, December 1999.

57 Could Futures Markets Help Growers Better Manage Coffee Price Risks in Costa Rica? by Peter Hazell, January 2000. 
58 Industrialization, Urbanization, and Land Use in China, by Xiaobo Zhang, Tim Mount and Richard Boisvert, January 2000.

59 Water Rights and Multiple Water Uses: Framework and Application to Kirindi Oya Irrigation System, Sri Lanka, by Ruth Meinzen-Dick and Margaretha Bakker, March 2000.

60 Community Natural Resource Management: The Case of Woodlots in Northern Ethiopia, by Berhanu Gebremedhin, John Pender and Girmay Tesfaye, April 2000.

61 What Affects Organization and Collective Action for Managing Resources? Evidence from Canal Irrigation Systems in India, by Ruth Meinzen-Dick, K.V. Raju, and Ashok Gulati, June 2000.

62 The Effects of the U.S. Plant Variety Protection Act on Wheat Genetic Improvement, by Julian M. Alston and Raymond J. Venner, May 2000.

63 Integrated Economic-Hydrologic Water Modeling at the Basin Scale: The Maipo River Basin, by M.W. Rosegrant, C. Ringler, D.C. McKinney, X. Cai, A. Keller, and G. Donoso, May 2000.

64 Irrigation and Water Resources in Latin America and the Caribbean: Challenges and Strategies, by Claudia Ringler, Mark W. Rosegrant, and Michael S. Paisner, June 2000.

65 The Role of Trees for Sustainable Management of Less-Favored Lands: The Case of Eucalyptus in Ethiopia, by Pamela Jagger and John Pender, June 2000. 